Research Report No. 25/2013

\title{
Fruitful Diversity: Revisiting the Enforceability of Gestational Carriage Contracts
}

Susan G. Drummond

Osgoode Hall Law School of York University, sdrummond@osgoode.yorku.ca

Follow this and additional works at: http://digitalcommons.osgoode.yorku.ca/clpe

\section{Recommended Citation}

Drummond, Susan G., "Fruitful Diversity: Revisiting the Enforceability of Gestational Carriage Contracts" (2013). Comparative Research in Law \& Political Economy. Research Paper No. 25/2013.

http://digitalcommons.osgoode.yorku.ca/clpe/272 


\section{OSGOODE}

OSGOODE HALL LAW SCHOOL YOR K U N I VERSITY

\section{OSGOODE HALL LAW SCHOOL}

Comparative Research in Law \& Political Economy

RESEARCH PAPER SERIES

Research Paper No. 25/2013

\section{Fruitful Diversity: Revisiting the Enforceability of Gestational Carriage Contracts}

Susan Drummond

Editors:

Peer Zumbansen (Osgoode Hall Law School, Toronto, Director Comparative Research in Law and Political Economy)

John W. Cioffi (University of California at Riverside)

Leeanne Footman (Osgoode Hall Law School, Toronto, Production Editor)

Comparative Research in Law \& Political Economy 
Fruitful Diversity: Revisiting the Enforceability of Gestational Carriage Contracts Susan G. Drummond, Associate Professor, Osgoode Hall Law School March, 3, 2013; Please do not cite without permission

Abstract: While the federal Assisted Human Reproduction Act was eviscerated by the Supreme Court challenge from Quebec to its constitutional integrity, the room allotted to the provinces to regulate aspects of assisted regulation remains to a large extent unoccupied. This is particularly evident in the domain of parentage law where a significant number of provinces have either thin statutory regulation or none at all, leaving dated common law principles to resolve disputes around parentage. Given that these common law principles were crafted in an era when assisted reproduction and the fracturing of biological, genetic, and intentional motherhood was inconceivable, the legislative lapse is significantly out of step with contemporary realities. This paper lays out the current state of parentage law in provincial regimes across Canada with respect potential conflicts between gestational carriers and intended parents. While the Uniform Child Status Act of 2010 - model legislation proposes a consolidation of the principle that the woman who gives birth is the mother, this paper draws upon the body of recent empirical research around gestational carriage to advance the argument that intended parents ought to prevail over gestational carriers in the event of post-natal conflict over parentage. 
Fruitful Diversity: Revisiting the Enforceability of Gestational Carriage Contracts

Susan G. Drummond, Associate Professor, Osgoode Hall Law School

March, 3, 2013; Please do not cite without permission

Fruitful Diversity: Revisiting the Enforceability

of Gestational Carriage Contracts ${ }^{1}$

Introduction

The aspirations of those who sought a set of national policies on reproductive technologies in Canada have been considerably dampened by the last three years of judicial and executive action at the federal level. In December of 2010, large portions of the federal Assisted Human Reproduction Act (AHRA) - the product of years of scholarly and policy deliberation - were ruled ultra vires by the Supreme Court of Canada in the Reference re Assisted Human Reproduction Act. ${ }^{2}$ Left with an eviscerated mandate, it was only a matter of time before the largely dysfunctional federal agency ${ }^{3}$ tasked with implementing and enforcing the act - Assisted

\footnotetext{
1 Throughout this chapter I have favoured the term "gestational carrier" over "surrogate" where possible as more reflective of the way in which the woman who carries the child and his or her intended parents view the relationship. I reserve the term "surrogacy" (often called "traditional surrogacy" in the literature) for the small faction of the situations associated with this means of bringing children to term in which the woman who carries the child is also genetically related to him or her. (See statistics cited in Busby, infra, note 114). The terminology of "gestational carriage" also has the virtue of not begging the legal question at issue in this paper, which is focused on the determination of legal parentage. To call a woman the surrogate "mother", even if borrowing colloquial usage, pre-judges the legal outcome that is at the heart of this paper. I recognize that the phrase "intended parent" also begs the legal question, however this terminology has more universal currency in the literature, along with "commissioning parent" - and usage in this case also comports with the argument that I will be making in this chapter.

2010 SCC 61, [2010] 3 S.C.R. 457 (hereinafter AHRA Reference)

3 See evidence, Parliament's Standing Committee on Health, $40^{\text {th }}$ Parliament, $3^{\text {rd }}$ Session, Tuesday, November 16, 2010 (testimony of Francoise Baylis et al); see also Francoise Baylis, "The Demise of Assisted Human Reproduction Canada", J Obstet Gynaecol Can 2012; 34(6): 511-13
} 
Fruitful Diversity: Revisiting the Enforceability of Gestational Carriage Contracts

Susan G. Drummond, Associate Professor, Osgoode Hall Law School

March, 3, 2013; Please do not cite without permission

Reproduction Canada - was abolished in the federal budget cuts of early $2012 .{ }^{4} \mathrm{~A}$ tattered patchwork of federal provisions remain in the $A H R A$, mostly held together by the federal criminal law power; however, their coverage is thin given that the scaffolding of regulation requisite for their effective coverage remains absent for some critical provisions of the Act (notably section 12 of the Act which relates to the reimbursement of expenses relating to gestational carriage) and given the almost complete absence of enforcement of the provisions that relate to gestational carriage and gamete donation. ${ }^{5}$

As a result of these developments, Canada's federal government currently has a weak regulatory presence in the field of assisted reproduction, most particularly gestational carriage. And the will to renew a national legal project appears phlegmatic despite (and no doubt because of) assisted reproduction norms - moral and market - that have been thriving, effectively unchecked, on the ground. ${ }^{6}$ By a considerable measure, provincial governments have remained uninvolved in the last 20 years of drama surrounding assisted reproduction while the federal government attempted to define the proper legislative and regulatory controls to govern the field. As a result, the provinces have for the most part refrained from occupying fields allocated to them under the constitutional division of powers. This is acutely evident in the area of parentage law where many provinces have failed to legislatively update their concepts of legal parentage to keep apace with the astonishing and various news ways in which families are now created.

\footnotetext{
4 See Anne Kingston, "Assisted Human Reproduction Canada: the budget cut everyone missed; The agency was largely useless but its shuttering curtails federal oversight of fertility treatments" McClean's Magazine, April 2, 2012; see also Sara Cohen "Bill impacts assisted human reproduction in Canada", AdvocateDaily.com, September 25, 2012

${ }^{5}$ See Alison Motluk, "The Human Egg Trade; How Canada's fertility laws are failing donors, doctors, and parents, The Walrus, April, 2010.

${ }^{6}$ See ibid.
} 
Fruitful Diversity: Revisiting the Enforceability of Gestational Carriage Contracts

Susan G. Drummond, Associate Professor, Osgoode Hall Law School

March, 3, 2013; Please do not cite without permission

The clearing left over the last two decades for legislatively ungoverned norms to flourish means that there is a considerable amount of empirical data as well as a swell of anecdotal tales in traditional and social media that might inform juridical norms. The governance lag - a lag that often seems perpetual in the area of assisted reproduction - has produced an auspicious moment to measure the appropriateness of both explicit legislative frameworks that render gestational carriage contracts unenforceable, as well as those provincial regimes (that remain the majority) in Canada that have not passed comprehensive (or even any) legislation in this area. Under both explicit statutory regimes and those governed by a default common law or outdated legislation, the woman who gives birth to a child becomes thereby the legal mother of the child, whether or not she has a genetic link to the child and whether or not she intended to occupy this position. This is the ancient common law rule of mater est quam gestatio demonstrat (hereinafter mater est) (by gestation the mother is demonstrated). This is the understanding of maternal legal parentage that for the most part prevails in common law Canada in the absence of legislated regimes; ${ }^{7}$ or is supplemented by child status legislation that references the "natural" mother (though drafted in a period when assisted reproduction was unimaginable); or is obliquely recapitulated in Vital Statistics legislation that defines birth as the complete expulsion or extraction of a child from its "mother". This chapter will argue that an alternative that barely dared speak its name in Canada after the 1988 Baby

\footnotetext{
7 For a review of the common law rules and statutory regimes that apply in provincial regimes across the country see Angela Campbell, "Conceiving Parents Through Law", 21 Int'l J.L. Pol. \& Fam. 242 2007; Roxanne Mykitiuk, "Beyond conception: legal determinations of filiation in the context of assisted reproductive technologies, Osgoode Hall Law Journal, 2001 Winter;39 (4):771-815 and Susan Boyd, "Gendering Legal Parenthood: Bio-Genetic Ties, Intentionality and Responsibility", (2007) 25 Windsor Y.B. Access Just. 63. These scholarly articles are somewhat dated and this chapter will update provincial statutory and common law accordingly.
} 
Fruitful Diversity: Revisiting the Enforceability of Gestational Carriage Contracts

Susan G. Drummond, Associate Professor, Osgoode Hall Law School

March, 3, 2013; Please do not cite without permission

$M$ debacle in the United States ${ }^{8}$ - the primacy of intentional parenting over gestational parenting in legal parentage - may finally have enough normative and empirical solidity to unseat the ancient rule.

The practical attenuation of the criminal prohibitions in the AHRA has left room for a considerable shift in the substratum of values associated with assisted reproduction. With the hobbling of legislation relating to assisted reproduction at the national level, the time is auspicious for private law (principally provincial) to respond to the surprising and complex family law implications of the last 20 years of conceiving children differently. This chapter will argue that the most appropriate response to developments would be to create legislative and regulatory frameworks under which gestational carriage contracts are enforceable.

\section{Current Provincial Laws on Gestational Contracts \\ Gestation over Intention}

The 1988 Baby $M$ case in New Jersey generated a staggering amount of contradictory scholarly literature on the family law implications of assisted reproduction. The tensions in the case were writ large on the academic stage where legal scholarship focused on the tension between contract law and the rights of gestational carriers and children as vulnerable parties. At the center of the case was a surrogate, Mary Beth Whitehead, whose egg was combined with intended parent William Stern's sperm. Stern was thus both a genetic and an intended father. The sole contribution of his wife Elizabeth, who had neither a biological nor a genetic

\footnotetext{
${ }^{8}$ In re Baby M, 537 A.2d 1227, 109 N.J. 396 (N.J. 02/03/1988); the Baby M case involved traditional surrogacy in the sense outlined in footnote 1 . I will discuss this case in more detail.
} 
Fruitful Diversity: Revisiting the Enforceability of Gestational Carriage Contracts

Susan G. Drummond, Associate Professor, Osgoode Hall Law School

March, 3, 2013; Please do not cite without permission

stake in the child's conception and delivery, was her intention to become the mother of the offspring. The intentions of each of these parties were embodied in a gestational carriage contract that stipulated that Whitehead would relinquish her parental rights in favour of Elizabeth Stern post-natally. Absent the contract, Whitehead's parental rights were implicit in the theretofore unchallenged assumption that the status of motherhood follows gestation, an assumption that Whitehead drew upon in her post-natal decision to keep the child as her own. The Stern's legal challenge to have the child recognized as the legal daughter of Elizabeth Stern as per the contract did not succeed, as gestational carriage contracts were held to be void as contrary to public policy. However, the father - who was on equal footing as a genetic parent with Whitehead vis a vis parentage - was granted custody on the basis of the child's best interests. The dispute was settled, in other words, on the basis of facts that sounded in custody, not parentage, law: the best interests of a particular child.

The characterization of the contest as one between status and contract - a legal elevation of the contest between biology and intention - was taken up in the academic literature. Linking the status of motherhood with gestation reproduced a state of affairs so obvious that it went without saying, the means for the establishment of maternity historically almost universally going without explicit mention in legislation dedicated to establishing legal parenthood for children. ${ }^{9}$ The linkage also intersected with more contemporary concerns about protecting the vulnerabilities of women, particularly in the face of asymmetries of class, and anxieties about the commodification of children. ${ }^{10}$ Entrenching the status of

\footnotetext{
${ }^{9}$ See Mykitiuk and Campbell, supra, note 7.

${ }^{10}$ This was the conclusion of the Royal Commission New Reproductive Technologies, Proceed with Care: Final Report of the Royal Commission on New Reproductive Technologies, vol. 2 (Ottawa: Minister of Government Services Canada, 1993)
} 
Fruitful Diversity: Revisiting the Enforceability of Gestational Carriage Contracts

Susan G. Drummond, Associate Professor, Osgoode Hall Law School

March, 3, 2013; Please do not cite without permission

motherhood through biology provided a bulwark against the encroachment of the unbridled market embodiment of intention in contract, and in particular commercial contract.

As detailed in the AHRA Reference, the federally-instituted Royal Commission on New Reproductive Technologies in Canada - created one year after the American Baby M spectacle - generated one set of policy responses to assisted reproduction that led eventually to legislation that could unify national policy by subsuming policy under the federal criminal law power. Shortly thereafter, in 1992, the Uniform Law Conference of Canada created the Uniform Child Status Act, which was accepted by the Bar Associations of Canada as a model for the civil - and therefore provincial implications of assisted reproduction. ${ }^{11}$ The model legislation, which reflects the will of no government or political authority, entrenched gestation over intention as the core determinant of legal maternal parentage by deeming a child's mother to be the woman who gives birth to him or her, whether or not her egg is used to conceive the child. While the model act provides basic rules speaking to a range of issues relating to parentage, the 2010 updating of the act reproduces the 1992 primacy of gestation over contract when it stipulates that "An agreement in which a surrogate arranges to relinquish a child conceived for that purpose is unenforceable.$^{12}$ The thrust of public policy with respect to gestational carriage contracts appears to have remained static over the last twenty years. I will argue that the model law in this regard is no longer

[RCNRT] for example at xxxii, 15, 22, 52, 107, 199, and Recommendations 199-205. The conclusions of the Royal Commission were supported by a large number of Canadian feminists. For a summary of these views and references to much of this literature, see Karen Busby, "Revisiting the Handmaid's tale: Feminist Theory Meets Empirical Research on Surrogate mothers" 26 Can. J. Fam. L. 132010 ... and for extensive references to the leading dominant feminist position supported by the Royal Commission see footnote 6 in particular

${ }_{11}$ Uniform Child Status Act, online Uniform Law Conference of Canada, Online at www.ulcc.ca/en/us/UNIFORM\%20CHILD\%20STATUS\%20ACT.doc

12 Section 8(11), Uniform Child Status Act, 2010. 
Fruitful Diversity: Revisiting the Enforceability of Gestational Carriage Contracts Susan G. Drummond, Associate Professor, Osgoode Hall Law School March, 3, 2013; Please do not cite without permission

adequate to deal with the complexities, legal, political, and emotional of gestational carriage.

It would be incorrect to characterize the Uniform Act, 2010 as forever precluding the possibility of intention surmounting gestation as a means of establishing parentage in the context of a gestational carriage arrangement. Indeed the Act lays out a straightforward procedure whereby intended parents can become legal parents following the birth of a child through gestational carriage through mutual agreement between the parties conjoined with declaratory relief. This agreement, however, is not rooted in the carriage contract but rather antedates it. I will return to the mechanism proposed in the Uniform Act. First I want to lay out parentage law as it currently exists in provincial common law and statute.

Legal parentage is a lifelong status that determines the existence of a parentchild relationship across a wide range of legal contexts and is the usual (though not determinative) starting point for the allocation of parenting responsibilities while the child is a minor. I will not be covering parentage law in detail in this analysis but will rather focus principally on those aspects of parentage law that relate to determinations of motherhood.

Parentage law (or filiation in Quebec) covers the relationship not only between child and mother, but all of the ways by which fathers become legal parents to children. ${ }^{13}$ While legal parentage for fathers can be rooted in unrebutted legal presumptions such as name on the birth certificate or relationship with the birth mother, in the case of the legal parentage of mothers, it has historically been uniquely based on birth (the mater est rule) and for the purposes of this chapter, I will principally focus on the link between the gestational and intended parents, who

13 See Mykitiuk, Campbell, and Boyd, supra, note 7; see also Fiona Kelly, "(Re)forming Parenthood: The Assignment of Legal Parentage within Planned Lesbian Families" (2009) 40 Ottawa Law Review, 185 
Fruitful Diversity: Revisiting the Enforceability of Gestational Carriage Contracts

Susan G. Drummond, Associate Professor, Osgoode Hall Law School

March, 3, 2013; Please do not cite without permission

may or may not have a genetic link to a child born of gestational carriage. This issue is spotlighted by virtue of the potential conflict at the heart of this chapter, namely the rare and juridically-untested case in Canada where both gestational carrier and intended parents claim legal parentage. ${ }^{14}$ Working through the statistically rare case of a conflict between parties to a gestational carriage contract - in the light of public policy and the most current empirical evidence - provides an opportunity to clarify the interests at stake in gestational carriage arrangements. ${ }^{15}$

In the rare event that a gestational carrier were to decide post-natally that she wants to be a mother to the child, Quebec provides a clear and certain rule about the legal outcome of the inevitable conflict that would ensue with intended parents, an outcome which requires no further legal action on the part of carrier. As the first province to extensively regulate assisted reproduction in the context of family law, Quebec passed article 541 of the Quebec Civil Code in 1991 under which "Any agreement whereby a woman undertakes to procreate or carry a child for another person is absolutely null." Regardless of who provides the sperm and egg that constitute the child's genetic makeup, and regardless of what the original intentions of all parties were regarding who would be the child's parent(s) and raise him or her, the woman who gives birth to the child is the presumptive mother - a status that can only be overcome by an adoption that breaks the links with the biological mother

\footnotetext{
${ }^{14}$ I will address the HLW and THW v. JST and JT, [2005] BC] No. 2616 (QB) case below - but that case sounded in custody as well as consent to adoption and the only reporting on the case relates to the interim issue of custody.

${ }^{15}$ As the overwhelming majority of contemporary cases where a woman carries a child through pregnancy for other (intended) parents do not involve a genetic linkage between her and the child, I will be restricting my analysis to that scenario - and suggesting that the enforceability of gestational carriage contracts be restricted to that form of gestational carriage - and leaving aside the possible implications of legal parentage for "traditional" surrogacy in which the woman carries a child to whom she has a genetic link.
} 
Fruitful Diversity: Revisiting the Enforceability of Gestational Carriage Contracts

Susan G. Drummond, Associate Professor, Osgoode Hall Law School

March, 3, 2013; Please do not cite without permission

and creates "fictional" links with new parents. ${ }^{16}$ Quebec is the only jurisdiction in Canada that compels intended parents in the context of gestational carriage, regardless of genetic link to the child, to proceed with an adoption in order to become that child's legal parents.

The common law provinces and territories have a mix of provisions that facilitate the creation of legal parentage in intended parents, however almost all of them have provisions rooted in common law or statute that recognize the woman who gives birth to a child as his or her mother. With the possible exception of Nova Scotia and Newfoundland and Labrador, none of them have opened the door for a grounding of legal parentage in the gestational carriage contract itself. Quebec, Alberta, and British Columbia are the only provinces in Canada that have taken the explicit position that such contracts are null and void, to wit, unenforceable. However it would be incorrect to characterize the situation in the remaining common law provinces and territories as one in which such contracts are enforceable. Indeed with the possible exception of Newfoundland and Labrador and perhaps Nova Scotia, Canadian provinces and territories tend not to recognize legal parentage on the grounds of the gestational carriage contract alone. In some cases, provincial law makes clear what legal result would ensue should the carrier choose to parent the child post-natally; in other cases it does not.

If common law provinces have not passed legislation that explicitly deals with legal parentage in the context of gestational carriage, an outdated common law prevails and parties must rely on judicial intervention in the event of a postnatal

${ }^{16}$ Notoriously, one Quebec judge refused to permit such an adoption to proceed on the basis that surrogacy contracts are null and void in Quebec, leaving the child parentless (Adoption -- 091, 2009 QCCQ 628); however subsequent cases in Quebec have declined to follow the precedent set by this case and have permitted intended parents to adopt the children whose birth they facilitated through gestational carriage. Adoption -- 09184, 2009 QCCQ 9058; Adoption -- 09367, 2009 QCCQ 16815; Adoption-10330 2010 QCCQ 17819 and Adoption 103292010 QCCQ 18645 
Fruitful Diversity: Revisiting the Enforceability of Gestational Carriage Contracts

Susan G. Drummond, Associate Professor, Osgoode Hall Law School

March, 3, 2013; Please do not cite without permission

conflict between intended parents and gestational carrier. Unsupplemented by legislation, provinces draw upon the mater est rule, a rule generated in an epoch where it was unthinkable that motherhood might vest in parties other than the biological mother (and also in her husband or male partner under rebuttable presumptions of paternity). Where legislation supplements this common law biological understanding of motherhood, two types of provincial legislation are typically drawn on: vital statistics legislation and child status legislation. The former, an administrative tool, permits the registration of parents as part of the documentation of birth. The resulting birth certificate creates a presumption of parenthood but is not itself determinative of legal parentage. The vast majority of parents create a lifelong status for their child through this original document that determines the existence of a parent-child relationship across a wide range of legal contexts, never needing to draw upon child status legislation that allows for judicial declarations of parentage affirming or denying the presumption created by a birth certificate.

Both vital statistics and child status legislation historically, for the most part, entrenched the common law rule that links motherhood to gestation and birth. ${ }^{17}$ Very slowly, provincial legislatures have begun to catch up with the realities of assisted reproduction to permit other mechanisms whereby intended parents might be registered as the child's parents or secure declarations of legal parentage.

British Columbia has passed the most recent legislation to deal with assisted reproduction and gestational carriage. In a larger revision to the provincial Family

17 See, for example, s. 96(1) New Brunswick Family Services Act, S.N.B. 1989, c.F2.2; s. 3(1), Newfoundland and Labrador, Children's Law Act, 1990, c.C-13; s. 2(1) Northwest Territories, Children's Law Act S.N.W.T., 1997, c.1; s. 1(1) Ontario Children's Law Reform Act, R.S.O. 1990, c.C.12; s. 1(1) Prince Edward Island Child Status Act, R.S.P.E.I. 1988, c.C-6; s. 40(1) Saskatchewan Children's Law Act SS. 1997, c.C-8.2; and s. 2(1) of Alberta's Family Law Act, S.A. 2004, c. F-4.5 
Fruitful Diversity: Revisiting the Enforceability of Gestational Carriage Contracts Susan G. Drummond, Associate Professor, Osgoode Hall Law School March, 3, 2013; Please do not cite without permission

Law Act that came into effect in March of 2013, parentage through gestational carriage is explicitly addressed by laying out the criteria and a mechanism for the creation of legal parentage in intended parents. While the legislation requires a written contract providing for legal parentage to the intended parents, that contract alone is insufficient to overcome the mater est rule. The gestational carrier further needs to consent post-natally to the transfer of legal parentage and the legislation permits the carrier to withdraw consent to the contract prior to birth. ${ }^{18}$ The new legislation does not require a court order for the transfer of parentage. Registration consistent with the consent requirements of the Family Law Act will suffice and a birth can be registered to intended parents on the day of birth; however if the gestational carrier refuses to provide consent a court order cannot vest legal parentage in accord with the original contract. The legislation is explicit that gestational carriage contracts are unenforceable and may not be used as evidence of the carrier's consent to a transfer of legal parentage; however the contract may be used as evidence of the intended parents' intentions with respect to parentage if a dispute arises after the child's birth so that if intended parents refuse to take steps to assume parentage post-natally despite the contract and the gestational carrier's consent to relinquish, the contract can be used to impute parentage to them. ${ }^{19}$

A number of those common law provinces that have passed child status legislation that specifically addresses gestational carriage similarly render the contract unenforceable on its own terms. Alberta also added a provision on surrogacy to its Family Law Act in 2003 and, following Quebec's lead, explicitly provided that "Any agreement under which a surrogate agrees to give birth to a child for the purpose of relinquishing that child to a person a) is not enforceable and b) may not

${ }^{18}$ See s. 29(3)(a) and (b)(i), British Columbia's Family Law Act which comes into force in 2013

${ }^{19}$ Ibid, section 29(6) 
Fruitful Diversity: Revisiting the Enforceability of Gestational Carriage Contracts

Susan G. Drummond, Associate Professor, Osgoode Hall Law School

March, 3, 2013; Please do not cite without permission

be used as evidence of consent of the surrogate [to a declaration of change of legal parentage to the intended parents. $]^{\prime 20}$ Unlike Quebec, however, intended parents do not need to go through the adoption process to acquire legal parentage; they can seek a declaration that permits them to register themselves as the legal parents of a child. However like British Columbia, this process requires that the gestational carrier gives birth to the child, that she understands that she is the parent of the child by virtue of having given birth (the mater est rule), and that she consents to the application to change parentage. ${ }^{21}$

Nova Scotia provides analogous provisions that allow intended parents to become legal parents in the context of assisted reproduction without adoption, however these provisions on gestational carriage are captured in the regulations to the Vital Statistics Act alone, and not in child status legislation. ${ }^{22}$ While not specifically addressing the enforceability of gestational carriage contracts these regulations enable intended parents to register the child provided that the "woman who is to carry and give birth to the child does not intend to be the child's parent".(Italics added) $^{23}$ This provision does not impose a positive obligation for the registration to be accompanied by the carrier's consent. The gestational carriage contract then might provide evidentiary weight in conjunction with the absence of the carrier's objection. However the ability of the gestational carrier to override a gestational contract post-natally by expressing an intent to parent renders such contracts unenforceable on their own terms, even if the "arrangements" (as they are called in the regulations) provide the foundation for successful registration. Further,

${ }^{20}$ s. $8.2(8)$ of the Family Law Act, S.A. 2003, C. F-4.5. This language is the same as the language in the Uniform Child Status Act, s. 8(11)

${ }^{21}$ Regulation 2(2)(b)(c) and(f) of the Alberta Family Law Act. Alberta also requires that one of the intended parents is genetically linked to the child.

22 See section 5(2) of the Birth Registration Regulations made under s. 51 of the Vital Statistics Act, R.S.N.S. 1989, c. 494

${ }^{23}$ Ibid, section $5(2)(\mathrm{c})$. 
Fruitful Diversity: Revisiting the Enforceability of Gestational Carriage Contracts

Susan G. Drummond, Associate Professor, Osgoode Hall Law School

March, 3, 2013; Please do not cite without permission

consistent with Alberta's legislation, one of the intended parents must have a genetic link to the child. ${ }^{24}$ Despite the inability of gestational carriage contracts to modify legal parentage on their own terms, Nova Scotia does lay out some bare minimums that such contracts would need to meet for the regulations to apply, namely that the "arrangements" had to have been initiated by the intended parents and must have been planned prior to conception. ${ }^{25}$ Nova Scotia in with British Columbia is specifying the requisite content that gestational carriage contracts require before legal parentage can be transferred to intended parents. British Columbia's requirements are more detailed and echo the requirement that the gestational carriage must be organized in advance of conception. Neither province requires that the carrier be legally represented by independent counsel.

Newfoundland and Labrador, like Alberta, permit declaratory orders of legal parentage that override the common law mater est rule. ${ }^{26}$ Even though an oblique reference to the mater est rule can be found in the definition of birth as "the complete expulsion or extraction from its mother" (italics added) in the Vital Statistics Act and the provision in the provincial child status act that "a person is the child of his or her natural parents" (italics added) ${ }^{27}$, the child can be registered subsequent to a declaration of legal parentage as the child of the intended parents.

\footnotetext{
${ }^{24}$ Ibid, section $5(2)$

25 The fact that other provinces tend to regard gestational carriage contracts as unenforceable means that little attention has been given to what ought to go into these contracts to safeguard the interests of the parties and larger public policy interests that are only intimated in Nova Scotia's regulations and British Columbia's child status legislation. There is no statutory prohibition in the other provinces on gestational carriage contract being entered into one day before birth leaving the distinction between gestational carriage and adoption somewhat blurry. I will address this concern when I review California's new surrogacy law.

${ }^{26}$ Sections 3 and 6 of the Children's Law Act, R.S.N.L. 1990, c.C-13.

27 "natural" is not defined
} 
Fruitful Diversity: Revisiting the Enforceability of Gestational Carriage Contracts

Susan G. Drummond, Associate Professor, Osgoode Hall Law School

March, 3, 2013; Please do not cite without permission

This rule issues from a 2009 amendment to the Vital Statistics Act that explicitly took into account gestational carriage. ${ }^{28}$

Unlike Alberta, however, the legislation is silent on whether or not the gestational carrier has to consent to the transfer of legal parentage, though this is implied by the oblique mater est references. The province's vital statistics and child status legislation are almost silent on the mechanism by which this presumption might be rebutted, noting only that "Where the court finds on the balance of probabilities that a woman is or is not the mother of a child, the court may make a declaratory order to that effect." ${ }^{29}$ This leaves open the possibility that the gestational carriage contract might be used as the only evidence to vest intended parents with legal parentage, such that Newfoundland and Labrador come closest to giving gestational carriage contracts such potential weight. Alberta and British Columbia (that also allow the contract to serve as an evidentiary foundation for assigning legal parentage) positively require the written consent of the carrier to the transfer post-natally.

Prince Edward Island amended its Child Status Act in 2008 to deal with assisted reproduction, however the legislation does not deal directly with gestational carriage, thus leaving the status of these arrangements in a similar position to those provinces that lack comprehensive legislation on legal parentage in the case of gestational carriage. ${ }^{30}$ The legislation is clear, however, that " $A$ woman who gives birth to a child is deemed to be the mother of the child, whether the woman is or is not the genetic mother of the child" ${ }^{31}$ making the transfer of legal parentage to intended parents

\footnotetext{
28 Section 5(6) of the Vital Statistics Act, 2009 S.N.L.2009 Chapter V-6.01

${ }^{29}$ Section 6(2) Children's Law Act, R.S.N.L. 1990, c.C-13. This is standard language in many child status laws across the country.

${ }^{30}$ See section 9(1) of the Child Status Act, R.S.P.E.I. 1988, c. C-6

${ }^{31}$ See section 9(7) Child Status Act, R.S.P.E.I. 1988, c. C-6
} 
Fruitful Diversity: Revisiting the Enforceability of Gestational Carriage Contracts

Susan G. Drummond, Associate Professor, Osgoode Hall Law School

March, 3, 2013; Please do not cite without permission

contemplated in gestational carriage contracts effectively dependent upon the carrier's consent.

In Ontario, Saskatchewan, New Brunswick and Manitoba, and the Territories, the possibility is present for a declaratory order of legal parentage to be granted to the intended parents despite the lack of explicit legislation outlining the process for legal parentage in the case of gestational carriage and despite incidental imbedding of the mater est rule in both child status and vital statistics legislation. The rule is embedded in language such as Ontario's Family Law Act that stipulates that "for all purposes of the law of Ontario a person is the child of his or her natural parents" (italics added). ${ }^{32}$ "Natural" is not defined in the legislation. In these provinces vital statistics legislation implicitly further entrenches the mater est rule, for example by defining birth as "the complete expulsion or extraction from its mother of a fetus that did any times after being completely expelled or extracted from the mother breathe or show any other sign of life."(Italics added.) ${ }^{33}$

Intended parents wanting to clarify and register their role as legal parents have needed to draw upon the scant case law in these provinces (most of which have no reported cases) in which judges have granted declaratory relief in scenarios where the gestational carrier consents, or declines to contest, an application made by intended parents. ${ }^{34} \mathrm{~A}$ judicial declaration of parentage is required if the registration is to override the common law biological presumption. Despite the lack of explicit legislation on gestational carriage, the leading Ontario case on point grounded the transfer of legal parentage in a provision of the Children's Law Reform Act that

32 s. 1(1) Children's Law Reform Act, R.S.O. 1990, c.C.12

${ }^{33}$ S. 1, Vital Statistics Act R.S.O. 1990, Chapter V.4. Other provinces have similar definitions of birth; see Vital Statistics Act, RSH 1988, c V-4, s. 2(1) Vital Statistics Act, SS 2009, c. V-7.21, s. 1 Vital Statistics Act, CCSM c. V60, s. 1, Vital Statistics Act, SNB 1979, c V-3

${ }^{34}$ See JR V LH [2002] O.J. \#3998 (Ont. S.C.); MD v. LL, 2008 CanLII 9374 (Ont.S.C.); JAW v. JEW 2010 NBQB 414; and WJQM v. AMA, 2011 SKQB 317 
Fruitful Diversity: Revisiting the Enforceability of Gestational Carriage Contracts

Susan G. Drummond, Associate Professor, Osgoode Hall Law School

March, 3, 2013; Please do not cite without permission

allows "any person having an interest to apply to court for a declaration that a male person is recognized in law to be the father of a child or that a female person is the mother of the child". ${ }^{35}$ This judicial interpretation of child status legislation has been further shored up by a second Superior Court judgment from Ontario that found that there was a "gap" in the provincial Vital Statistics Act because its imbedded definition of "mother" through birth no longer accorded with developments in assisted reproduction. The "gap" that was relied upon in the $A A v . B B$ and $C C$ case that allowed for the registration of three parents on a birth certificate through an invocation of the court's parens patriae jurisdiction ${ }^{36}$ was used to find legal parentage in intended parents despite the archaic language of the act. ${ }^{37}$

Given that the oblique reference to the mater est rule in these types of legislation is vulnerable to supplemental judicial law-making, and given the broad reading of "any person having an interest" that includes intended parents, there may be a narrow door open in these provinces for gestational carriage contracts to be the evidentiary source of a declaration of parentage for intended parents. However the alternative implication of residual mater est rules is that a contract will not be enforced on its own terms as the child is born the child of the gestational carrier and there is no statutory room for the contract to apply of its own force to supplant this status.

This is indeed how the Court of Queen's Bench in Manitoba interpreted the provincial Vital Statistics Act in the face of an application by intended parents for a pre-birth order for a declaration that the hospital documentation of the child's birth

${ }^{35}$ JR v LH [2002] O.J. \#3998 (Ont. S.C.) citing s. 4(1) of the Children's Law Reform Act,

${ }^{36} A A$. V. BB and CC (2007), $35 \mathrm{RFL}\left(6^{\text {th }}\right)$ ONCA (hereinafter $A A$ v. BB and CC); the parens patriae jurisdiction is defined in that case at para 27 as follows: "The court's inherent parens patriae jurisdiction may be applied to rescue a child in danger or to bridge a legislative gap."

37 MD. v. LL (2008), 52 RFL (6 $\left.6^{\text {th }}\right) 122$ (Ont. Sup. Ct. J.) 
Fruitful Diversity: Revisiting the Enforceability of Gestational Carriage Contracts

Susan G. Drummond, Associate Professor, Osgoode Hall Law School

March, 3, 2013; Please do not cite without permission

show them to be the "natural and legal parents" of the child delivered through gestational carriage. The court relied on the definition of birth as "the complete expulsion or extraction from its mother" and denied the application. (Italics added) ${ }^{38}$ This interpretation of oblique and dated mater est references in VSA's and child status laws is, however, by no means settled in law, particularly given the growing tendency of courts to use their parens patriae jurisdiction where they perceive a legislative "gap". That leaves the legal status of gestational carriage contracts in considerable limbo.

Despite the oblique persistence of the mater est rule, on the strength of the handful of cases that recognize declaratory orders as a mechanism for assigning legal parentage to intended parents declaratory relief has become routine in those provinces that have failed to pass explicit legislation that deals with legal parentage in the context of gestational carriage, with the effectively untested proviso that the gestational carrier does not contest the application. ${ }^{39}$

There is only one case on record in Canada of a carrier - in this case a surrogate as per the definition in footnote 1 - contesting the parentage provisions outlined in a gestational contract. ${ }^{40}$ In that British Columbia case both the carrier and intended father were genetically linked to the child. Post partum, both parties sought custody and the surrogate refused to give consent to the intended mother's adoption. The genetic father and his wife had custody and, on an interim judgment this arrangement persisted with the carrier denied interim access. This is all that is

\footnotetext{
38 JC v. Manitoba (2000), 12 RFL ( $5^{\text {th }} 274$ (Man. QB)

${ }^{39}$ Karen Busby cites the following statistics: "One Ontario lawyer has handled more than 1500 surrogacy arrangements while an Alberta lawyer's website states that she has "helped hundreds" with surrogacy contracts. A British Columbia lawyer testified that he made applications in more than 75 surrogacy cases between 2003-11 and a Vancouver ART clinic states that it "performs gestational carrier surrogacy for 15-20 couples each year." Cited in "Of Surrogate Mother Born". Paper in author's possession.

${ }^{40}$ HLW and THW v. JST and JT, [2005] BC] No. 2616 (QB)
} 
Fruitful Diversity: Revisiting the Enforceability of Gestational Carriage Contracts Susan G. Drummond, Associate Professor, Osgoode Hall Law School March, 3, 2013; Please do not cite without permission

on record of this case; an unusual one in the context of current practice around gestational carriage in that the surrogate was also genetically related to the child and an unsatisfying one with respect to clarifying the outcome of a contest between intended parents and gestational carriers.

Summarizing the status of gestational carriage contracts in the common law provinces and territories of Canada, only Alberta explicitly states that the contracts are unenforceable and cannot be used as evidence. With the possible exception of Newfoundland and Labrador and Nova Scotia, all other common law jurisdictions either have not legislatively overridden the mater est rule (in which case the status of gestational carriage contracts remains somewhat obscure) or explicitly provide that a declaration or registration of legal parentage in the intended parents cannot proceed without the consent of woman who gives birth to the child or children. Nova Scotia and Newfoundland and Labrador leave open the possibility that a court might find, on a balance of probabilities, that a gestational carriage contract is sufficient to find that gestational carrier is not the mother of a child. Nova Scotia and British Columbia are alone in laying out some minimum standards that gestational "arrangements" need meet to position an intended parent to claim legal parentage. In the context of this diverse patchwork of provisions on legal parentage in the context of assisted reproduction, it is fair to say that Canada has barely begun to deal with the growing reality of gestational carriage with five provinces (PEI, Ontario, Manitoba, New Brunswick and Saskatchewan) and the territories lacking any legislation dealing directly with the new reality, two provinces with thin legislation (Newfoundland and Labrador and Nova Scotia), and only three provinces passing anything resembling a comprehensive approach to assisted reproduction that includes treatment of gestational carriage (Quebec, Alberta and British Columbia). 
Fruitful Diversity: Revisiting the Enforceability of Gestational Carriage Contracts

Susan G. Drummond, Associate Professor, Osgoode Hall Law School

March, 3, 2013; Please do not cite without permission

\author{
Unifying Canadian Parentage Law \\ The Uniform Child Status Act
}

While the $A H R A$ was intended to be legislation that could unify national policy around assisted reproduction by subsuming large parts of the field under the federal criminal law power, in the above private law context the Uniform Child Status Act of 2010 seeks to generate a unified national policy for the private law aspects of assisted reproduction, including gestational carriage. The Uniform Act proposes comprehensive legislation covering all aspects of child status, including the more common parentage scenario where assisted reproduction is not involved; but it also directs a concerted eye towards several aspects of how assisted reproduction changes the rules of parentage. Section 8 , in particular, is devoted to declaratory orders respecting parentage where gestational carriage has been involved.

The model law remains aspirational, given that it was generated by government policy lawyers and analysts, private lawyers, and law reformers rather than legislatures. Rather than cover the entire section that deals with declarations of parentage relating to gestational carriage contracts, I want to focus on those provisions that stand to affect their status as enforceable agreements, ${ }^{41}$ principally because I want to argue that they serve as a poor model for provincial legislation around legal parentage with respect to gestational carriage contracts, and the rationale invoked to support the model is inadequate to a proper analysis of the field. I will argue that the inadequacy of the model legislation indicates that the framework of those American states that explicitly regulate enforceable gestational carriage

\footnotetext{
41 The general provision on "Declaratory orders respecting parentage - surrogacy" can be found at s. 8 of the model act; and those provision that relate to the enforceability and evidentiary value of gestational carriage contracts can be found at s. $8(11)$.
} 
Fruitful Diversity: Revisiting the Enforceability of Gestational Carriage Contracts

Susan G. Drummond, Associate Professor, Osgoode Hall Law School

March, 3, 2013; Please do not cite without permission

contracts would be better suited to the realities of gestational carriage that have emerged over the last two decades. ${ }^{42}$

The Uniform Act starts with an explicit entrenchment of the mater est rule: "The following persons are the parents of a child: his or her birth mother". ${ }^{43}$ This is followed by a set of presumptions about how other parties become legal parents common to all child status legislation; and the mechanism of declaration of parentage by a court that is already common to most child status legislation in Canadian provinces. ${ }^{44}$ In this regard, the Uniform Act differs from Quebec in not requiring intended parents to adopt a child who is born the legal parent of the birthmother-née-gestational-carrier. They need only have an interest, which would be generated by intention to parent plus a genetic link to the child or a spousal relationship with the former party. The Uniform Act proposes explicit provisions that deal with both assisted reproduction and gestational carriage.

For the Uniform Act, gestational carriage agreements can serve as an evidentiary foundation for the legal parentage of intended parents, but only to the extent that they provide evidence of the latters' intention to parent post-natally. This provision would serve admirably to lessen the chances that a gestational carrier might find herself the legal parent of a child that she did not set out to gestate for that purpose. It does not, however, bind the intended parents to their original intention as gestational carriage contracts are unenforceable under the Uniform Act. ${ }^{45}$ The contract cannot serve as evidence of the carrier's consent to relinquish legal parentage, no matter how explicit the terms of the contract. These provisions

42 See Elizabeth S. Scott, "Surrogacy and the politics of commodification", Law and Contemporary Problems 72.3 (Summer 2009); and for more comparative work, also see Judith F. Daar, Reproductive Technologies and the Law (Newark, New Jersey: LexisNexus Matthew Bender, 2006)

43 s. 3(2)(a) Uniform Act, 2010

44 s. $3(2)$ (b) (iii)

${ }^{45}$ s. 8(11) Uniform Act. 
Fruitful Diversity: Revisiting the Enforceability of Gestational Carriage Contracts Susan G. Drummond, Associate Professor, Osgoode Hall Law School March, 3, 2013; Please do not cite without permission

shore up the Act's explicit mater est rule which makes the gestational carrier the legal mother upon birth until a declaratory order to the contrary is made. Both she and the intended parents would have to share parental rights and responsibilities pending the order (though such a declaratory order can have retroactive effect to the time of birth). Consent for a relinquishment of legal parentage, in other words, can only issue post-natally. Evidentiary considerations aside, the Uniform Act is clear that gestational carriage contracts, on their own terms, are unenforceable and at most provide evidentiary weight in favor of a carrier's intention not to parent. These provisions are consistent with Alberta's Family Law Act.

In the comments that accompany these provisions of the Uniform Act, the rationale invoked is the following:

Subsection (11) clarifies that surrogacy agreements are unenforceable. It is not consistent with public policy or with the court's overarching parens patriae responsibilities to allow surrogacy contracts to be enforceable. Note Jane Doe v. Alberta, (2007), 278 D.L.R. $\left(4^{\text {th }}\right) 1$, which references the inability of an agreement between the parties to bind the hands of the court.

In Jane Doe, it was held that it is not in the best interests of children that their parentage can be contractually designated or limited in advance. ${ }^{46} \mathrm{~A}$ couple in a romantic relationship wished to contractually limit the male partner's parental status and obligations with respect to a child, conceived through sperm donation, who the mother wanted to parent exclusively. They wanted to contractually preclude the de facto acquisition of the status of social parent for the man, as his ongoing relationship with the mother might generate the kinds of relationship and reliance

${ }^{46}$ Doe v. Alberta, 2007 ABCA 50(hereinafter Jane Doe) 
Fruitful Diversity: Revisiting the Enforceability of Gestational Carriage Contracts

Susan G. Drummond, Associate Professor, Osgoode Hall Law School

March, 3, 2013; Please do not cite without permission

that ordinarily enable a court to attribute fatherhood - with its attendant rights and obligations. The rights and obligations of de facto parents have been affirmed by the Chartier case briefly discussed below. ${ }^{47}$

The Jane Doe case did not turn on the best interests of the particular child, which had not been argued, but on whether the policy in the provincial legislation permitting courts to override private parental agreements violated the contracting parties' liberty as protected by section 7 of the Canadian Charter of Rights and Freedoms. The Alberta Court of Appeal upheld trial judge's finding that Jane Doe's spouse would "stand in place of parent" as per the provincial Family Law Act regardless of his intent to not parent. The statute says that a person stands in the place of parent if he or she is the spouse of the child's parent or is "in a relationship of interdependence of some permanence" with the parent, and has demonstrated a settled intention to treat the child as his or her own. As to the determination of settled intention, the court weighed Jane's spouse's actions and the nature of the spouse's relationship, but they also found that his choice to remain in the commonlaw relationship with the mother indicated his reality as parent to her child. His future conduct might manifest a settled intention to treat Jane's child as his own. The Court of Appeal regarded the emergence of this relationship as effectively inevitable. ${ }^{48}$ The commentary to the Uniform Child Status Act finds analogy between

\footnotetext{
${ }^{47}$ See infra note $X X$

48 "The Appellants ask how can it be said that a person has demonstrated a "settled intention" to take on a parental obligation when there is a personal statement of intent from the outset which is contrary to that? In my opinion, the answer is to be found in the context of the relationship between Jane and John Doe. The "settled intention" to remain in a close, albeit unmarried, relationship thrust John Doe, from a practical and realistic point of view, into the role of parent to this child. Can it seriously be contended that he will ignore the child when it cries? When it needs to be fed? When it stumbles? When the soother needs to be replaced? When the diaper needs to be changed?" Doe v. Alberta, 2007 ABCA 50 at paras 21-22.
} 
Fruitful Diversity: Revisiting the Enforceability of Gestational Carriage Contracts Susan G. Drummond, Associate Professor, Osgoode Hall Law School March, 3, 2013; Please do not cite without permission

gestational carriage contracts and the proposed contract between Jane Doe and her spouse.

\section{An Alternative Model for Canadian Parentage Law Intention over Gestation}

This paper will scrutinize this rationale by contrasting the policy driving the model law (unenforceable gestational carriage contracts) with the policies that drive the alternative (enforceable contracts). It will also address the empirical realities that challenge other long-standing justifications for minimizing the place of the intention of the parties to such a contract. The proposed alternative would preclude the situation that, at any time following birth, parents from two families who are otherwise strangers in law would continue to share rights and responsibilities that flow from legal parentage. Rather than create certainty by rendering gestational carriage contracts null and void (as Quebec has done), the alternative would create certainty by rendering the contract enforceable in that it provides all the requisite evidence for the consent of both carrier and intended parents for legal parentage to vest in the intended parents; and it would be a new self-standing foundation for declaratory orders of parentage: the enforceability of contract. This certainty would just as effectively clarify responsibilities and rights from the moment of birth onwards.

This certainty has been characterized as "heartless" by the preponderance of Canadian policy analysts on this topic since the Baby $M$ case in New Jersey. Rosemarie Tong's sentiments, for example, have found an echo in Canadian policy when she notes that 
Fruitful Diversity: Revisiting the Enforceability of Gestational Carriage Contracts

Susan G. Drummond, Associate Professor, Osgoode Hall Law School

March, 3, 2013; Please do not cite without permission

Women as a whole will benefit from an approach that stresses their right, not their duty, to be mothers (and not simply baby machines). The adoption approach, with its change of heart clause, replaces what strikes me as the heartless contract approach. A deal is not always a deal - at least not when one is trading in some of the deepest emotions human beings can ever feel. Any approach that binds women to reproductive decisions - as does the contract approach - must be regarded with deep suspicion. ${ }^{49}$

The "heartlessness" of gestational carriage contracts has long been advanced as one, among many, reasons for resisting their enforceability on public policy grounds. I will revisit these arguments momentarily. For now I want to lay out the alternative as it is articulated in California's new surrogacy law which is a jurisdiction that has been immersed in a very different policy climate around assisted reproduction over the last two decades. The differences in context are often jarring enough that Canadian policy analysts and law reformers almost reflexively turn away from the Californian model. That reflex may be impulsive.

California judicially considered the very issue of the enforceability of gestational carriage contracts two decades ago in a case where the intended parents both had a genetic link to the child another woman carried and gave birth to. The argument that gestational carriage is appropriately analogized to adoption, which affords a period for "change of heart" post-natally, was weighed in Johnson v. Calvert (hereinafter Johnson)..$^{50}$ The court also considered whether the gestational carrier had at least an equal right to legal parentage upon birth due to the strong emotional connection

${ }^{49}$ Rosemarie Tong, "Feminist Perspectives and Gestational Motherhood: the Search for a Unified Legal Focus" in Joan C. Callaghan, ed., Reproduction, Ethics, and the Law: Feminist Perspectives (Bloomington and Indianapolis, IN: Indiana University Press, 1995) 55 at 75.

50851 P.2d 776 - 1993 
Fruitful Diversity: Revisiting the Enforceability of Gestational Carriage Contracts Susan G. Drummond, Associate Professor, Osgoode Hall Law School March, 3, 2013; Please do not cite without permission

created by carrying a child and considered the argument that the tie-breaker between those equal claims should be broken by consideration of the best interests of the child. ${ }^{51}$ Ultimately, however, in Johnson, none of these arguments prevailed in the majority decision. The Court endorsed the view of Professor Hill that "while all of the players in the procreative arrangement are necessary in bringing a child into the world, the child would not have been born but for the efforts of the intended parents. $[T]$ he intended parents are the first cause, or the prime movers, of the procreative relationship" and held that the one who intended to "bring about the birth of a child that she intended to raise as her own -- is the natural mother under California law." (Italics added).

The primacy of intention over biology in matters of legal parentage was extended to cases where intended parents have neither genetic nor biological links to the child. Five years after Johnson, the court in Re Marriage of Buzzanca herineafter Buzzanca $)^{52}$ clarified that the enforceability of gestational carriage contracts "was not limited to just Johnson-style contests between women who gave birth and women who contributed ova, but to any situation where a child would not have been born "'but for the efforts of the intended parents."' With the results in these two cases, gestational carriage contracts enforceably determined legal parentage thereafter in Californian parentage law for similar situations. And intended parents have been able to get pre-birth orders that clarify that they have all of the rights and responsibilities of legal parentage upon birth.

California recently passed a gestational carriage law, effective since the beginning of January 2013, that entrenches and formally regulates the common law

\footnotetext{
${ }^{51}$ These were the arguments that were favored by the dissent in the case.

52 In re Marriage of Buzzanca, 61 Cal.App.4th 1410, 72 Cal.Rptr.2d 280 (Ct. App. 1998)
} 
Fruitful Diversity: Revisiting the Enforceability of Gestational Carriage Contracts

Susan G. Drummond, Associate Professor, Osgoode Hall Law School

March, 3, 2013; Please do not cite without permission

generated by Johnson and Buzzanca. ${ }^{53}$ While the law was originally an extensive attempt to regulate a large range of practices associated with assisted reproduction in California, it was ultimately whittled down to a codification of best legal practices associated with gestational carriage contracts. ${ }^{54}$

The clarification of legal requirements for enforceable gestational carrier contracts was in some measure stimulated by the outrage surrounding an international scam with roots in California in which American women were recruited to travel abroad for the implantation of embryos created by brokers in the absence of intended parents. Once past their first trimester of pregnancy, the gestational carriers and the fetuses they were carrying were marketed to prospective parents for $\$ 150,000$ on the ruse that the original intended parents had backed out of the agreement. The lawyers and co-ordinator who perpetrated the scam were convicted of wire fraud and monetary transactions in property derived from illegal activity.

Stimulated by this debacle, California's Surrogacy Law now requires that intended parents and gestational carriers be represented by separate counsel and that their agreement be notarized for binding effect. The execution and notorization of the agreement has to be completed prior to the administration of medications used in assisted reproduction or any embryo transfer procedure and requires the parties to the contract to attest, under penalty of perjury, to their compliance with the provisions of the Act. The Act further codifies past practice in permitting intended parents to establish a parent and child relationship in law consistent with the intent

${ }^{53}$ See sections 7960 and 7962 of the California Family Code (Hereinafter California Surrogacy Law). California is not the only American state to recognize the enforceability. See Elizabeth S. Scott, "Surrogacy and the politics of commodification", Law and Contemporary Problems 72.3 (Summer 2009); and for more comparative work, also see Judith F. Daar, Reproductive Technologies and the Law (Newark, New Jersey: LexisNexus Matthew Bender, 2006)

54 Judy Daar, "California Surrogacy Bill Reacts to Lawyer Bad Acts", September 17, 2012, Harvard: Petrie-Flom Centre blog 
Fruitful Diversity: Revisiting the Enforceability of Gestational Carriage Contracts

Susan G. Drummond, Associate Professor, Osgoode Hall Law School

March, 3, 2013; Please do not cite without permission

expressed in the agreement prior to the child's birth by filing a parentage action under the Uniform Parentage Act. In this manner, upon birth, legal parentage can be clarified from the moment that potential medical decisions need to be made along with the exercise of other parental rights and responsibilities and the parent(s) who needs to register the birth is known from the start.

The California Surrogacy Law need not be taken as the be-all-and-end-all of gestational carriage contract law. There are features of Canadian parentage law and clinical practice that might be drawn upon to supplement these elements. While not permitting pre-birth orders and still requiring the post-natal consent of the gestational carrier for legal parentage to be ordered consistent with the contract, the British Columbia Family Law Act echoes California's requirement that a written agreement must be made prior to conception for the arrangement to qualify as gestational carriage. It further stipulates content to the agreement for its validity, to wit the agreement must provide that the carrier will not be a parent of the child, that the carrier will surrender the child to the intended parent or parents, and that the intended parent(s) will be the child's parent(s). ${ }^{55} \mathrm{~A}$ sensible gestational carriage contract that reflects dominant clinical practice might also require that gestational carriers have completed their own families, that they not use their own gametes or those of their spouses, and that they have clarified their wishes, feelings, motivations and intentions through a counselor who specializes in gestational carriage. ${ }^{56}$

55 Section 29(2)(a) and (b) of the Family Law Act

56 These requirements would comport with current clinical practice. Empirical studies indicate that almost all gestational carriers have had children and completed their family; see summary of research in Karen Busby, "Revisiting Handmaid's Tale..." at 48. Busby's article also covers the empirical studies that indicate that clinics and agencies only agree to work with women who have given birth; also at 48 
Fruitful Diversity: Revisiting the Enforceability of Gestational Carriage Contracts

Susan G. Drummond, Associate Professor, Osgoode Hall Law School

March, 3, 2013; Please do not cite without permission

If Canadian provinces were to adopt the provisions of the California Surrogacy Law (perhaps amplified with Canadian law and practice as well as drawing on other jurisdictions that regulate enforceable contracts) the remnants of the mater est rule in Vital Statistics law would need to be revised such that the definition of "birth" does not foreclose the possibility of a displacement of biological motherhood by a gestational carriage contract. This would not require the elimination of the mater est rule (though it should probably be more explicit than current oblique references in Vital Statistics and child status legislation. After all, outside the context of assisted reproduction and gestational carriage, the rule is certainly useful to the extent that most women who give birth are unequivocally the legal mothers of their children short of adoption or a finding of unfitness. Child status legislation would have to add a provision that recognizes the possibility of legal parentage arising from a gestational carriage contract either through declaratory order or birth registration. Those provinces that have created explicit rules that require post-birth consent from the gestational carrier for a transfer of legal parentage would have to revise their regimes; a fortiori those provinces that explicitly rule gestational carriage contracts unenforceable. Before such legislative reforms could even be contemplated, the public policy rationales for the current regimes need to be revised and reconsidered. And it is to this undertaking that I now turn.

\section{Risk and Certainty}

In those provinces that have created an explicit statutory trump for the gestational carrier with respect to legal parentage, the virtue of the approach is underlined by the certainty it generates in advance of the child's birth and in 
Fruitful Diversity: Revisiting the Enforceability of Gestational Carriage Contracts Susan G. Drummond, Associate Professor, Osgoode Hall Law School March, 3, 2013; Please do not cite without permission

advance of conflict between intended parents and gestational carriers. Ostensibly, no one need go to court as the outcome of a legal parentage dispute would be clear in advance. The child and his or her family can set about consolidating the family around this certainty from the outset of birth. However in those provinces that declare gestational carriage contracts null and void, the consequences of such certainty are borne by all parties, but in different measures. Of the risks (some of which are theoretical in that there is no empirical evidence that they have recently, commonly, or ever arisen), the trump of gestation over intention exposes the implicated individuals and their kin differently. And there are many configurations of misery that can flow from this apparently certain rule.

In light of the absence of comprehensive statutory clarity about the treatment of gestational carriage contracts - both in provinces that explicitly declare them unenforceable and of limited evidentiary value and in those that are silent on both issues - there is residual uncertainty about the outcome should intended parents refuse, on birth, to adopt the child, or to seek a declaration of legal parentage in their favor, or register their names on the birth certificate. While Quebec, for example, has amended its civil code to account for "parental projects" involving assisted reproduction, the language of the provisions is directed to those situations where "a person alone decides or spouses by mutual consent decide, in order to have a child, to resort to the genetic material of a person who is not party to the parental project." ${ }^{57}$ (Italics added) A genetically related intended parent is a party to a parental project - just not the one in consideration in the amended code; and genetically-unrelated intended parents are completely outside of consideration. Quebec is thus silent on what would happen if intended parents declined to apply for

57 Article 538, Civil Code of Quebec, L.R.Q., c. C-1991 
Fruitful Diversity: Revisiting the Enforceability of Gestational Carriage Contracts

Susan G. Drummond, Associate Professor, Osgoode Hall Law School

March, 3, 2013; Please do not cite without permission

an adoption as per the terms of a contract that the civil code regards as null and void.

A recent Canadian situation illustrates an instance where such a scenario might arise. The gestational carrier in a story cited in the National Post originally refused to abort a fetus with Down's Syndrome, despite the instructions of the intended (and genetic) parents and a contract that stipulated that the surrogate would become the legal mother if she did not respect the intended parent's instructions on termination. ${ }^{58}$ Canadian law does not allow anyone but the woman carrying a child to control her body (for example her diet, her medical treatment, and her weight), including the decision to terminate a pregnancy. That constitutional limitation, however, does not control all of the private law implications for her decision namely whether a woman can be obliged to become a legal parent to a child she carries for intended parents. The new Family Law Act of British Columbia would not transfer legal parentage to intended parents if the gestational carrier refuses to consent to the transfer; however if the intended parents refuse to apply for legal parentage, the contract can be used as evidence regarding parentage intentions. But in this case, the terms of the contract provide ambiguous evidentiary assistance. It is not clear that they intended to bring this particular child into the world; there is evidence that that was explicitly NOT their intention - just as there is evidence that it was. $^{59}$

58 See Tom Blackwell, "Couple urged surrogate mother to abort fetus because of defect" National Post, Oct 6, 2010

59 The resolution of the tension in this case did not ultimately result from an interpretation of the contract or any other legal intervention: the gestational carrier eventually chose to have the abortion, partly because of her own family obligations. If anything, this scenario makes clear that greater regulatory attention to the gestational carriage contracts is required - an attention that has been lacking partly because they are effectively unenforceable in Canada under the mater est rule or explicit statutory language. 
Fruitful Diversity: Revisiting the Enforceability of Gestational Carriage Contracts

Susan G. Drummond, Associate Professor, Osgoode Hall Law School

March, 3, 2013; Please do not cite without permission

As it stands in British Columbia, a genetic link to the intended parents coupled with their (qualified) intention to parent creates the likely prospect of an imputation of legal parentage, presuming that the gestational carrier (now birth mother) makes an application as a "person with an interest" to attribute parentage. As gestational carriage contracts have not had the occasion to be judicially reviewed in Canada, it is not clear whether family law, which delineates obligations on genetic intended parents, would prevail over the contract or whether the latter could override family law obligations; nor is it clear what would happen if neither intended parent had a genetic link to the child.

This scenario speaks to a serious peril in regimes in which contracts ${ }^{60}$ are unenforceable: the child may have legal parents from two different families. Given that child status laws define parentage for a whole range of parental rights and obligations defined in other areas of family law including child support, custody, and access, the perils are both financial and psycho-social on a life-changing scale. There are various permutations of risk involved, from carriers becoming parents against their wishes to intended parents sharing parental rights and responsibilities with carriers against their original intentions, to carriers sharing parental rights and responsibilities with intended parents against their wishes, to intended parents losing all rights and responsibilities for children they intended (and yearned) to bring into the world. These permutations of peril differ from province to province. In those provinces that have not passed child status legislation dealing with gestational carriage, the situation is very uncertain; though there are risks for provinces like Alberta, Quebec, British Columbia that have done so and also risks under the model proposed by the Uniform Act.

60 Hereinafter "gestational carriage contract" will be used interchangeably with "contract"; and "gestational carrier" with "carrier". 
Fruitful Diversity: Revisiting the Enforceability of Gestational Carriage Contracts Susan G. Drummond, Associate Professor, Osgoode Hall Law School March, 3, 2013; Please do not cite without permission

For those provinces lacking statutory guidance, there is a mere handful of cases that lay out the course courts and parties might follow in the event of a breakdown in the "arrangement". The $J R v$. LH case in Ontario provides a type of roadmap but struggles to articulate ratios beyond the confines of the facts in that case - a "good news case" which involved two genetically related intended parents, a gestational carrier and her husband, all four of whom were in agreement with the intended parents application for legal parentage. ${ }^{61}$ As Judge Kitely notes, "There is no issue as to the enforceability of the gestational carriage agreement". ${ }^{62}$ The case cannot stand for a judicial ruling on how gestational carriage contracts should be read in the event of a dispute regarding parentage.

As noted above, s. 4(1) of Ontario's Childrens Law Reform Act allows for applications for "any person having an interest" to apply for a declaration of parentage. ${ }^{63}$ This language is common to many child status laws in Canada. For genetically-related intended parents, this section could be invoked by the carrier (or her male spouse) for parentage to vest in the intended parents. The use of this kind of provision is the usual route whereby mothers apply for declarations of legal parentage for genetic (or "natural" in the language of many statutes) fathers who might otherwise deny paternity. Legal parentage can be attributed to both men and women who have made a genetic contribution to a child on this basis, however provincial legislation generally precludes the attribution of legal parentage to gamete donors who did not intend to parent. ${ }^{64}$ But genetically-related intended parents clearly DO intend to parent, and so are both liable to a declaration of parentage

61 J.R. v. L.H., [2002] O] No. 3998 (Sup. Ct. J.) (hereinafter JR. v. LH)

${ }^{62}$ Ibid, para 8

63 This language is standard in many child status legislation across the country.

64 See, for example, s. 24(1) of British Columbia's Family Law Act; s. 12 (6) Newfoundland and Labrador Children's Law Act, R.S.N.L. 1990, C.C-13; s. 4(6) Child Status Act R.S.P.E.I. 1988, c. C-6; Article 538.2 Civil Code of Quebec, L.R.Q., c.C1991 
Fruitful Diversity: Revisiting the Enforceability of Gestational Carriage Contracts

Susan G. Drummond, Associate Professor, Osgoode Hall Law School

March, 3, 2013; Please do not cite without permission

against their wishes and able to apply for a declaration of parentage as "interested parties".

This may be a matter of concern if only one of the intended parents made a genetic contribution but both intend(ed) to parent the child; but it might also be a matter for concern where intended parents used donated sperm and egg for the embryo that is implanted in the carrier. Indeed the uncertainty generated by this kind of situation spills over into Nova Scotia's and Alberta's legislation (and the Uniform Act) given the statutory requirement in both provinces for a genetic link to at least one of the intended parents in order for a parentage order to properly vest in intended parents leaving the result more uncertain when such a link is absent in both intended parents. ${ }^{65}$

For those common law provinces with no explicit statutory language dealing with gestational carriage (or thin language), the road map in $J R v$. $L H$ is sketchy at best. Judge Kitely cites the genetic relation of the intended parents as the reason for the ready application of s. 4(1) CLRA, leaving it less clear what would happen in the absence of this connection. ${ }^{66}$ And it was this genetic link with the intended parents that further allowed a rebuttal of the presumption in child status legislation that the birth mother's spouse was the father. ${ }^{67}$ While the judge recognized that child status

\footnotetext{
${ }^{65}$ Section 8.2(1) Family Law Act, S.A. 2003, c. F-4.5: An application may be made to the court for a declaration that (b) a person whose human reproductive material or embryo was provided for use in the assisted reproduction is a parent of that child. Also see section 5(2) of the Birth Registration Regulations made under s. 51 of the Vital Statistics Act, R.S.N.S. 1989, c. 494

66 "The blood tests indicate that the probability that JR and JK are the mother and father respectively is greater than $99.99 \%$. I find that on a balance of probabilities they are the genetic parents of the twins. Pursuant to s. 4(1), JK is entitled to be "recognized in law" as the father of the children and JR is entitled to be "recognized in law" to be the mother of the children." JR $v$. $L H$, para 11.

67 "[The gestational carrier's husband" did not contribute genetic material. He is not the biological father. He is involved because he is the husband of the woman who is the gestational carrier and, pursuant to section 8(1) of the Children's Law Reform
} 
Fruitful Diversity: Revisiting the Enforceability of Gestational Carriage Contracts

Susan G. Drummond, Associate Professor, Osgoode Hall Law School

March, 3, 2013; Please do not cite without permission

legislation does not permit a court to make negative declarations as to parentage (such as declaring a gestational carrier to be a non-parent) a resolution for the collective aspirations of the two families was found in the Courts of Justice Act which provides for a superior court to make a binding declaration of right; this is the mechanism by which the gestational carrier was declared to be not the mother of the twins, despite the oblique mater est rule in the Vital Statistics Act that definitionally links "birth" to "mother". But Judge Kitely is also clear that the ability of the court to invoke the Courts of Justice Act in this way is dependent on the lack of opposition to the transfer of legal parentage.

While the reference to lack of opposition in $J R V$. $L H$ was to the gestational carrier's opposition, the opposition of the intended parents might also pose a problem: "If the application had been opposed, the omission from the application [of a request for declaratory relief] may have been problematic]". That the failure of the intended parents to seek declarative relief might also pose a problem is highlighted by the judge's reference to the Johnson $v$. Calvert case from California, discussed above, in which the gestational carriage contract was contested. Judge Kitely notes in obiter that "If such a conflict existed, I would have to consider whether s. 4(1) enables a declaration that there is more than one mother. ${ }^{68}$ In light of the lack of clarity in a situation where intended parents refuse to pursue their undertakings in the gestational carriage, the risks are considerable not only to the gestational carrier and her family, but also to any child born in these circumstances.

In the absence of the contract's enforceability on its own terms, the mechanism by which a judge would assign parentage in this scenario is somewhat obscure, particularly if there is no genetic link to a party, and particularly in those provinces

Act, he is presumed to be the father of the children. The presumption has been rebutted." JR V. $L H$, para 12.

$68 J R$ V. $L H$, para 18 
Fruitful Diversity: Revisiting the Enforceability of Gestational Carriage Contracts Susan G. Drummond, Associate Professor, Osgoode Hall Law School March, 3, 2013; Please do not cite without permission

that do not legislatively state the evidentiary weight that might be attributed to the contract. The best interests of the child standard from custody law (proposed by the dissent in Johnson v. Calvert) will have little purchase in these circumstances. The standard for functional parenthood (based not on genetic or biological connections to children but on having stood in place of parent $)^{69}$ or the status quo ante will not have any play in the early weeks of the child's life.

Chartier v. Chartier is the leading case in Canada that creates parentage rights and responsibilities in "functional" parents, or those who stand in place of parent. The Court held that a step parent who is found to be "in loco parentis" cannot unilaterally withdraw from the family relationship. The determination of whether an adult stands in the role of parent is made by taking account of a number of factors, including whether the child participates in the extended family in the same way as would a biological child; whether the person provides financially for the child (depending on ability to pay); whether the person disciplines the child as a parent; whether the person represents to the child, the family, the world, either explicitly or implicitly, that he or she is responsible as a parent to the child; the nature or existence of the child's relationship with the absent biological parent. But in the case of contested parentage relating to gestational carriage no one has yet occupied the functional role of parent; and no pattern of parenting has been established such as to create a status quo that should be maintained in the child's best interest - one of the other criteria for determinations of custody under the best interests rule.

In addition to the risks to carriers and their families of the unenforceability of contracts, and the risks to the children of genetically-linked intentional parents, the risks to the intentional parents are more manifest in the case of a dispute about parentage between the carrier and intended parents. If intended parents are genetic

${ }^{69}$ See Chartier v. Chartier, 19991 SCR 242 (hereinafter Chartier). 
Fruitful Diversity: Revisiting the Enforceability of Gestational Carriage Contracts

Susan G. Drummond, Associate Professor, Osgoode Hall Law School

March, 3, 2013; Please do not cite without permission

parents as well as intentional parents, in light of current laws that link custody and support to genetic connections ${ }^{70}$ they risk being responsible for children that are torn between families from the outset. As noted with respect to Ontario, which has child status laws similar in this respect to many other common law provinces of Canada, "any person having an interest" can seek a declaration of parentage and can clearly do so with respect to intended parents with a genetic link to a child. A carrier who decides to withhold consent to a transfer of legal parentage retains the ability to have a genetically-related intended parent of either gender declared a legal coparent for purposes such as child support. The language used by Judge Kitely in $J R$ $v$. $L H$ to attribute exclusive parentage to genetically-related intended parents could be imported virtually without change - with "obligatorily" substituted for "entitled to" in such a context given reflecting the reality that parenthood involves both responsibilities as well as rights:

The blood tests indicate that the probability that [genetic contributors] are [legal parents] is greater than $99.99 \%$. I find that on a balance of probabilities they are the genetic parents. Pursuant to s. 4(1), [such an intended parent] is [obligatorily] "recognized in law" as the [parent] of a child. ${ }^{71}$

The intended parent would be responsible for a child that they are precluded from exclusively parenting as per their best-laid plans. Indeed it is possible they would be responsible for supporting a child financially that they are not parenting at all or very little. While legal parentage can be assigned to them on the foundation of their genetic link and intention to parent, determinations about custody and access are

\footnotetext{
${ }^{70}$ With the exceptions of anonymous donor insemination which breaks the kinship link (and attendant obligations) between genetic progenitors and children.

${ }^{71}$ Substituted language from $J R v$. $L H$, para 11
} 
Fruitful Diversity: Revisiting the Enforceability of Gestational Carriage Contracts Susan G. Drummond, Associate Professor, Osgoode Hall Law School March, 3, 2013; Please do not cite without permission

made in the best interests of particular children. These are fact-driven determinations and there is no legal necessity linking joint legal parentage with a joint physical custody order. The case law compelling legal parents to persist in joint physical custody of children despite ongoing conflict is thin. Alternatively child support obligations are routinely assigned to legal parents who do not share a residence with a child.

In light of uncertainties about the evidentiary weight of contracts for those intended parents without a genetic link outlined above, all intended parents are at risk of being assigned parenting responsibilities for children they are not raising, or not raising exclusively in accordance with the contract. As noted, Alberta and British Columbia are quite explicit about the ability to use contracts as evidence of the parties' intentions with respect to parentage if a dispute arises after the child's birth. There may be some mitigation of the risk under Alberta legislation as it is explicit that an application attributing legal parentage cannot result in the child having more than two parents. ${ }^{72}$ The Uniform Act also has this limitation in its general parentage provisions that limit the number of parents a child can have by declaratory order. ${ }^{73}$

This limitation goes against the grain of an emerging common law mechanism that allows more than two parents to be registered on birth certificates under Vital Statistics laws, for example two lesbian mothers and the known gay man who donated the sperm, each of whom intend to jointly parent the child. ${ }^{74}$ But more to the point, such a provision does not prevent the two legal parents being the birth mother-neé-gestational-carrier and a genetically related intended parent. This can happen if the carrier has no spouse. The genetically-related intended parent would

\footnotetext{
72 See section 9(7)(b) of Alberta's Family Law Act

${ }^{73}$ Section 6(8)(b), Uniform Act

74 AA v. BB and CC cited supra note 36; see also Fiona Kelly, "(Re)forming Parenthood: The Assignment of Legal Parentage within Planned Lesbian Families" (2009) 40 Ottawa Law Review, 185
} 
Fruitful Diversity: Revisiting the Enforceability of Gestational Carriage Contracts

Susan G. Drummond, Associate Professor, Osgoode Hall Law School

March, 3, 2013; Please do not cite without permission

be the other legal parent. But it is also possible for two families to be raising a child born of gestational carriage even if both parties had spouses. The spouses of both the carrier and genetically-intended parent (if such parties are present) may well be found to be social parents, ${ }^{75}$ as the presumption of paternity in the carrier's male spouse could be rebutted by genetic fatherhood in another party, particularly given that the carrier's spouse had no original intention to parent the child. Following Jane Doe, canvassed above, the carrier's husband could not unequivocally preclude the status of social parent being assigned to him or her. It is difficult to see why the reasoning in that case, here modified to the facts of gestational carriage contracts gone wrong, would not prevail here as well:

The "settled intention" to remain in a close relationship [with the birth-motherneé-carrier] thrust[s] [the carrier's spouse] from a practical and realistic point of view, into the role of parent to this child. Can it seriously be contended that he will ignore the child when it cries? When it needs to be fed? When it stumbles? When the soother needs to be replaced? When the diaper needs to be changed? ${ }^{76}$

The same reasoning would apply to the genetically-related parent's spouse. As both the Jane Doe case and Chartier lay out, the rights and obligations of those standing in place of parent don't obliterate rights and obligations of legal parents but are able to operate alongside them. Both a "natural" father, for example, and a stepfather can owe child support.

\footnotetext{
${ }^{75}$ Following Chartier, see supra, note 69

76 See Doe v. Alberta, supra note 76 and associated text.
} 
Fruitful Diversity: Revisiting the Enforceability of Gestational Carriage Contracts Susan G. Drummond, Associate Professor, Osgoode Hall Law School March, 3, 2013; Please do not cite without permission

In the case of British Columbia, the evidence generated by the gestational carriage contract does not only bear upon those intended parents who made a genetic contribution to the child, as that statute does not require a genetic link in at least one of the intended parents. The incomes of both intended parents (if there are more than one) may be implicated under child support legislation.

That intended parents don't necessarily disappear as legal parents (though they might wish to) in the face of a decision by the carrier to retain legal parentage points to a further set of possibilities that could jettison each of the parties (including the child or children and any other family members) into an uncertain and fraught set of multiple family relations. This scenario would be precluded in Quebec as an adoption is required to create legal parentage in the intended parents; an adoption that can be blocked by the birth-mother-née-gestational-carrier. But intended parents are poised to become legal parents in the common law provinces.

Through the same mechanism in child status laws that allows an imputation of legal parentage to unwilling intended parents, "any person having an interest" can allow intended parents, particularly if genetically related to the child, to insert themselves as co-parents into the families of carriers that retain legal parentage. As the evidentiary weight of the contracts has not been judicially tested the ability of intended parents with no genetic link might also fall into this category. It ought not to be assumed that intended parents who have invested financially, emotionally, and likely genetically in the birth of a child will want to disappear from that child's life once the gestational carrier opts to pursue legal parentage. This scenario of multiple legal parents between more than one family, each of whom are legal strangers to each other outside of the gestational arrangement is strongly intimated in Judge Kitely's obiter that in the case of conflict "I would have to consider whether s. 4(1) enables a declaration that there is more than one mother". This would introduce a 
Fruitful Diversity: Revisiting the Enforceability of Gestational Carriage Contracts

Susan G. Drummond, Associate Professor, Osgoode Hall Law School

March, 3, 2013; Please do not cite without permission

new born child into the center of a vortex in which multiple parents would be poised to claim custody and access, a context that would likely be fraught given the decay of agreement from the outset of the child's life. ${ }^{77}$ While divorce has risks for all children, in these cases children would be born into a divorce-like scenario at the center of the centrifugal forces of two families that had no original desire to be entwined with each other.

If the various scenarios in which legal parentage can be attributed to both intended parents and a gestational carrier who opts to retain legal parentage seem far-fetched, the British case of CW $v N T$ \& Anor gives some pause. ${ }^{78}$ In that case the intended father, who was genetically related to the child, owed child support payments to the surrogate (who was also the genetic mother) as an aspect of the same default rules around child support that exist in Canada, namely that genetic parents owe child support. This was despite the fact that the surrogate retained full custody of the child - contrary to the original intentions of the parties - and the intended parents voluntary relinquished access to the child so that the child would not be split between two homes that had never intended to be connected.

Where the carrier opts to retain legal parentage, the scenario of intended parents being ascribed legal parentage against their wishes or choosing to pursue co-legal parentage with the gestational carrier/birth mother and her spouse present considerable risks for intended parents, for gestational/birth parents, and for the children caught up in such possible scenarios. But intended parents might also opt to abandon all claims to parentage of their intended child when the gestational carrier claims legal parentage. Here the risk is high for intended parents in another sense -

\footnotetext{
77 That the Whiteheads called Baby M "Sara" while the Sterns called her "Melissa" is the tip of the iceberg of possible ways in which a child might be torn in several directions from the outset of their lives.

${ }^{78}$ CW v NT \& Anor [2011] EWHC 33 (Fam) (21 January 2011)
} 
Fruitful Diversity: Revisiting the Enforceability of Gestational Carriage Contracts Susan G. Drummond, Associate Professor, Osgoode Hall Law School March, 3, 2013; Please do not cite without permission

or rather a risk present from the beginning of the project materializes. With the lack of enforceability of gestational carriage contracts intended parents always bear the risk of the loss of whatever financial contribution they have made to the child's creation and gestation as well as their intense emotional and psychological investment in plans to become parents with the carrier's assistance. They are perpetually vulnerable to this shattering of aspirations when gestational carriage contracts are unenforceable on their own terms. Leaving these vulnerabilities unprotected might be construed as heartless as readily as the contracts themselves have been described as heartless. In both cases, one is "trading in some of the deepest emotions human beings can ever feel. ${ }^{\prime 79}$

The rule that gestational carriage contracts are void is intended to protect general interests such as the best interest of children and the vulnerabilities of women as well as particular carriers and individual children. The policy of protecting these general interests can leave other vulnerable groups at risk. It might not just be individual intended parents who are more exposed under the mater est rule in gestational carriage situations, but also a significant percentage of those who use assisted reproduction and are members of marginalized groups within society. The case of a Michigan gestational carrier who decided to retain parentage and custody of twins because of the intended mother's "mental illness" hints at how problematic might be the birth mother's discretion to keep the child following the mater est rule. ${ }^{80}$ In that case the intended mother and her husband were the genetic parents of the children. Under Michigan law, as in Quebec, the gestational carrier is the presumptive mother of children born through surrogacy and legal parentage is only transferred to intended parents through the process of a formal adoption, which

\footnotetext{
${ }^{79}$ See Rosemarie Tong cited above at note 38

80 See Stephanie Saul, "Building Baby, With Few Ground Rules", New York Times, December 12, 2009
} 
Fruitful Diversity: Revisiting the Enforceability of Gestational Carriage Contracts

Susan G. Drummond, Associate Professor, Osgoode Hall Law School

March, 3, 2013; Please do not cite without permission

requires the birth mother's consent and is subject to a "change of heart" provision. The twins had already been yielded to the intended parents for a month when the gestational carrier "discovered" at the preliminary hearing for an adoption determination that the intended mother had a minor criminal record and a "mental illness" and decided not to consent to the legal transfer of parentage. As a result, the carrier and her husband retained custody.

The surrogate's personal assessment that the intended mother was unfit to parent, despite expert testimony to the contrary, underscores how morally messy the non-enforcement of gestational contracts can be. Supporting the argument that gestational carrier contracts should not be enforced is an awareness that there are currently no public policy limits on such contracts that would align them with general interests such as the best interests of children and women. But there is a counterpart to anxieties about insufficient attention to public policy on the side of those who argue the contracts should be enforced, namely that blanket unenforceability has no public policy limits that engage central social values such as non-discrimination. The change of heart can be provoked by a whim as easily as it might be provoked by retrograde social values such as racism or homophobia. Without enforceability, the arrangement is shielded from legal scrutiny. Given the high rate of non-traditional families formed out of assisted reproduction (including single and LGBTQ parents for example) ${ }^{81}$, it is not difficult to imagine how precariously the mater est rule leaves marginalized groups.

\footnotetext{
${ }^{81}$ Stu Marvel notes that "in 2008 it was estimated that as much as $15-25 \%$ of client traffic at Toronto-area fertility clinics is comprised of people from LGBTQ communities." Cited in "Tony Danza is My Sperm Donor?: Queer Kinship and the Impact of Canadian Regulations Around Sperm Donation"; paper in author's possession.
} 
Fruitful Diversity: Revisiting the Enforceability of Gestational Carriage Contracts

Susan G. Drummond, Associate Professor, Osgoode Hall Law School

March, 3, 2013; Please do not cite without permission

In summary, the rule that gestational carriage contracts are unenforceable on their own terms provides some prospective certainty regarding a dispute as to legal parentage in gestational carriage contracts. But it is also attendant with risks and further uncertainties that are redistributed elsewhere - and not only, as we have seen, to the intended parents, but also to carriers, their families, and the children born of the arrangements. A rule that the contracts are enforceable redistributes risk differently, but does not eliminate it altogether.

A law favoring a presumption of parenthood as laid out in the gestational carriage contract would also create certainty. Intended parents and carriers would know in advance which party would prevail in a legal contest over parentage: the intentions embodied in the contract would in principle prevail, barring the faults that otherwise nullify contracts generally and barring the context-specific contractual safeguards that might be added in keeping with legislation such as California's Surrogacy Law. Here too risks would be potentially borne by all parties, but in different measures.

In addition, more general risk-bearers would also emerge from such a legal rule: surrogates as a class, women as a group, and children. The gestational carrier risks the removal of a child to whom she has grown attached throughout the pregnancy, attendant with all of the anguish (though in a different, more embodied way) that the intended parents would experience under the alternative legal rule. The individual child has more certainty around who his or her parents will be in the scenario in which intended parents are identified as parents early in the process (at birth, or shortly thereafter, or even before birth) and that certainty is unmuddied by the possibility of two families having co-parentage status. However, a risk to children in general emerges from the context of a child having been created by forces more aligned with the marketplace and contract than the "natural" forces of affection or 
Fruitful Diversity: Revisiting the Enforceability of Gestational Carriage Contracts

Susan G. Drummond, Associate Professor, Osgoode Hall Law School

March, 3, 2013; Please do not cite without permission

attraction of the traditional family. This risk to children in general created by the context of gestational carriage is mirrored by a risk to women and carriers in general arising out of the creation of a group or class of women whose reproductive capacities are put at the disposal of third parties, a risk magnified by the possibilities that economic asymmetries might induce into surrogacy women who might not otherwise be disposed to the potential difficulties and risks of pregnancy and the corresponding risks of attachment. In light of constitutional guarantees of women's autonomy and integrity throughout pregnancy, the intended parents bear the risk of becoming parents to a child that they might not themselves have carried to term and the risk of becoming parents in circumstances that may have changed unfavorably from the date of the original contract.

There is, then, the virtue of certainty that arises from a clear rule about the enforceability, or lack thereof, of gestational carriage contracts. The related risks fall differently and in different measures on different parties depending on which rule is chosen. ${ }^{82}$ The enforceability of gestational carriage contracts also precludes the necessity of doing a fact-driven assessment of the best interests of the child - the golden rule for determinations relating to children within family law. As noted above, this avoidance of fact-based assessments makes sense in the context of gestational carriage in that most of the standard criteria used to interpret a particular child's best interests, such as stability, status quo, and determination of the primary caregiver, do not have a temporal foundation on which they can be built at the very moment when parentage might be contested (i.e., at or around birth).

\footnotetext{
82 The lability in the field of assisted reproduction and in the social norms associated with the technology suggests that a synopsis of foreseeable risks may well be incomplete and only as partial as the section of the field of possibilities to which we have already been exposed.
} 
Fruitful Diversity: Revisiting the Enforceability of Gestational Carriage Contracts Susan G. Drummond, Associate Professor, Osgoode Hall Law School March, 3, 2013; Please do not cite without permission

In light of how gestational carriage does not square easily with custody law, a rule regarding the enforceability of the contracts might be better established on the basis of policy determinations about the best interests of children in general, as opposed to a specific child. And this general standard is in fact one of the justifications provided in the commentary by the Uniform Child Status Act, 2010 (Uniform Act) for its proposal that provinces pass legislation rendering gestational carriage agreements unenforceable. A legal policy of enforcing gestational carriage contracts (as in California) carries risks as does a policy of refusing to enforce them. As I have tried to lay out, both policies have some potentially heartless consequences. Turning to a more scrupulous consideration of the public policy concerns and to the evidence of the empirical studies around gestational carriage might generate better ways of allocating the risks. A closer scrutiny of the rationales underlying the Uniform Child Status Act of 2010 is a profitable starting point for this re-thinking.

Contracts and Family Law: The Aptness of Doe in the gestational carriage context

As noted above, the comments to section 8(11) of the 2010 Uniform Act draw upon an Alberta Court of Appeal decision from 2007 as the legal rationale for voiding contracts that delineate legal parentage in advance, the Jane Doe case canvassed above. The Jane Doe case itself was not uncontroversial with respect to social parentage and the ability for parties to contractually create the type of family that suits their individual interests. Brenda Cossman, notably, was critical of the imposition of a narrow nuclear conception of family and parenthood on the potential 
Fruitful Diversity: Revisiting the Enforceability of Gestational Carriage Contracts

Susan G. Drummond, Associate Professor, Osgoode Hall Law School

March, 3, 2013; Please do not cite without permission

creativity arising from how individuals contractually construct their conception of family. ${ }^{83}$ In Cossman's view the ongoing relationship between spouses should not necessarily impinge on an exclusive parental relationship between one of the spouses and a child. ${ }^{84}$ In particular, she felt that women's ability to choose distinct romantic and parenting relationships was impeded by the ability of a court to impose a parental relationship regardless of contractual parental intention. Cossman's emphasis on intentional parenting fits into an emerging alternative to the traditional nuclear family that emphasizes a new paradigm of families by choice - or created families. ${ }^{85}$ Although the paradigm of intentional parenthood extends to the scenario of the Jane Doe case it also speaks well to the scenarios of same-sex partners/spouses and families created by reproductive technologies - not infrequently overlapping family forms. ${ }^{86}$

Beyond the critique Cossman offers regarding the suppression of contract in the context of parties who will continue to be in some kind of relationship with a child, it is not evident that the analogy promoted by the Uniform Act is effective in

83 See Brenda Cossman, "Parenting Beyond the Nuclear Family: Doe v. Alberta", Alberta Law Review, (2007) 45 Alta. L. Rev. 501 - 513

${ }^{84}$ This argument could be extrapolated to the case of a carrier's spouse where the former decides to retain legal parentage post-natally in Alberta and under the Uniform Act, both of which limit the number of parents a child can have to two. I argued above that the spouses of the carrier and genetically-related intended parent could be ascribed status as social parents with the latter being the two legal parents. Cossman's argument is not really available for this purpose, however, given that the overall thrust of the Alberta law and the Uniform Act is to undermine intention in the creation of families, something that Cossman's argument is structured to shore up.

85 See, e.g., Martha Albertson Fineman, Our Sacred Institution: The Ideal of the Family in American Law and Society, 1993 Utah L. Rev. 387,389 n.8; Elvia R. Arriola, Law and the Family of Choice and Need, 35 U. Louisville J. Fam. L. 691,694 (1997); R. Alta Charo, And Baby Makes Three-or Four, or Five, or Six: Redefining the Family after the Reprotech Revolution, 15 Wis. Women's L.J. 231, 242 (2000); Richard Storrow, "Parenthood By Pure Intention: Assisted Reproduction and the Functional Approach to Parentage" 53 Hastings L.J. 597 2001-2002; Cossman and Bruce Ryder, "What is 'Marriage-Like' Like? The Irrelevance of Conjugality" (2001) 18 Canadian Journal of Family Law, 269

${ }^{86}$ Supra, note 76 
Fruitful Diversity: Revisiting the Enforceability of Gestational Carriage Contracts Susan G. Drummond, Associate Professor, Osgoode Hall Law School March, 3, 2013; Please do not cite without permission

the context of gestational carriage contracts. The type of contract envisaged in Jane Doe is fully contemplated within the family law model of domestic contract. Family Law legislation across the country contemplates limitations on the kinds of contracts that already constituted "families" can enter as a means of avoiding default legislative regimes. Hence it is, across Canada, acceptable to contract out of the default property regimes imposed by family law statutes that more or less divide assets equally between spouses upon dissolution. It is now possible to enter domestic contracts that deal with division of spousal assets before, during, and at the termination of the relationship. Courts are generally reluctant to set aside a domestic contract on matters of assets unless there is a clear violation of basic rules of contract law (such as unconsionability, fraud, error, or duress). ${ }^{87}$ In contrast, parties are generally precluded from agreeing how they wish, between themselves, to deal with possession of the matrimonial home or custody of children until the point of separation. As for custody, courts are able to review contracts not only for standard contractual adequacy, but also for the best interests of children. As an indication of how far the supervisory reach of the court goes on matters of children, it is possible for a court to bar a divorce if a judge determines that child support arrangements are inadequate. ${ }^{88}$

But this anxiety about contracts relating to children, custody, and support is directed to families that are more or less already constituted around a traditional conception of the family; they are "domestic" to the extent that there is a recognizable family domain, which the contract aspires to regulate, even in its dissolution. They are not contracts between strangers. In the case of a gestational carriage contract, however, there is no already constituted family. In fact what is at

87 See the leading cases of v. Miglin [2003] 1 SCR 303 and Hartshorne v. Hartshorne [2004] 1 SCR 550

${ }^{88}$ See s. $11(1)$ (b) of the Divorce Act, R.S.C., 1985, c. 3 (2nd Supp.) 
Fruitful Diversity: Revisiting the Enforceability of Gestational Carriage Contracts

Susan G. Drummond, Associate Professor, Osgoode Hall Law School

March, 3, 2013; Please do not cite without permission

stake is the constitution de novo (with the child) of a family. To presume that gestational carriage contracts fall under the rubric of domestic contract begs the question about which family the child, as between two possible groups of effective strangers to each other, will enter into a domestic arrangement with. Before the contract is enforced or not, there is no ongoing domestic relationship. Furthermore, the intention of the parties to a contract is generally to preclude the emergence of a domestic relationship arising among the carrier, intended parents, and child.

Further, if a gestational carriage contract is honoured and kinship links are contractually severed between the gestational carrier and the child, there would be no place for any but the intended parents to be social parents. Unlike the Jane and John Doe scenario where the contract between the parties contemplated ongoing opportunities for functionally parental (or "parent-like") relationships to develop, there would be no place for carriers to develop a settled intention to treat the child as their own if the contract were honoured; there would be no emotional or financial reliance that develops between the child and the gestational carrier. ${ }^{89}$ The idea that family law should govern gestational carriage arrangements because the agreements made in contemplation of the birth of a child through this means are "domestic contracts" skews both the nature of family law and the nature of these arrangements. ${ }^{90}$ Family law issues such as custody and the special limits on domestic contracts only come into play once the issue of parentage is already determined, particularly when the gestational carrier has no genetic link to the child, as is

\footnotetext{
${ }^{89}$ I will address later the presumed emotional ties between gestational carrier and child that are claimed to arise from the intimate bodily experience of carrying him or her.

${ }^{90}$ For the contrary argument, namely that determinations of parentage, even in cases of assisted reproduction, should be made according to the principles of family law, not contract law, see Juliet Guichon, "The body, emotions and intentions: challenges of preconception arrangements for health care providers" (2007) 176 Canadian Medical Association Journal 479
} 
Fruitful Diversity: Revisiting the Enforceability of Gestational Carriage Contracts

Susan G. Drummond, Associate Professor, Osgoode Hall Law School

March, 3, 2013; Please do not cite without permission

overwhelmingly the case in current clinical practice. ${ }^{91}$ Custody arose as an issue in the Baby M case only by virtue of Mr. Stern's competing genetic link with the child. If he had no genetic connection, family law as it then was would have had no purchase. If Mary Beth Whitehead had had no genetic link, then the question of the set of parents to which family law should apply would have arisen in a very different manner. Calling the arrangement a custody issue rather than a contract issue construes Whitehead's and Stern's status as respectively maternal and paternal from the outset. And the policy issue of why gestational carriage contracts should not be honoured remains unanswered. That it is a family matter is precisely what is in question as the matter of which set of adults will become the child's family is yet unanswered.

In light of the ways in which a gestational carriage contract is distinct from a domestic contract, and in light of the absence of the risks contemplated in Jane Doe of children relying on the settled intentions and conduct of adults who interact with them for prolonged periods "as if" they were parents, it seems more appropriate to regard the gestational carriage contract as a contract between strangers; or perhaps as a sui generis contract in family law that has a distinct policy content that limits contractual freedom, such as the best interests of children (in the plural) and the social and economic interests of women (in the plural). Whether those policy

${ }^{91}$ Cf Karen Busby: "While most surrogate mothers until the late-1980s would have been impregnated by assisted insemination and therefore are the genetic mothers of the children, by 1994, about 50 percent of surrogacies involved the implantation of an embryo created using the genetic materials of others. This figure climbed to 95 percent by 2003" Karen Busby citing Heléna Ragoné "Of Likeness and Difference: How Race is Being Transformed by Gestational Surrogacy" in Helena Ragoné \& France Winddance Twine, eds., Ideologies and Technologies of Motherhood-Race, Class, Nationalism [New York: Routledge, 2000) [Ragon6, "Of Likeness and Difference"] and David P. Hamilton, "She's Having Our Baby: Surrogacy is on the Rise as In Vitro Improves" The Wall Street Journal (4 February 2003) online: The Wall Street Journal in Karen Busby, "Revisiting the Handmaid's Tale: Feminist Theory Meets Empirical Research on Surrogate Mothers" 26 Can. J. Fam. L. 132010 (hereinafter Revisiting Handmaid's) 
Fruitful Diversity: Revisiting the Enforceability of Gestational Carriage Contracts

Susan G. Drummond, Associate Professor, Osgoode Hall Law School

March, 3, 2013; Please do not cite without permission

concerns are best dealt with by the proposal to view all gestational carriage contracts as null and void is a question to which I will return. But first I want to turn to the ways that assisted reproduction expands the place of contract and intention in the creation of new family forms in a manner consistent with trends away from statusbased conceptions of the family - whether that status arises through marriage or biology. ${ }^{92}$ When conjoined with same-sex family models and the rise of singleparenthood, intention-based parenthood contributes to more diverse and individually-tailored conceptions of the structure of the family.

The structure of the family and its place within contemporary society was exploding in venues other than assisted reproduction at the same moment that technology was opening up other means of locating the place of children (in fact and in law). Several commentators noted the shift from status to contract in family law that characterized the last 40 years of the $20^{\text {th }}$ century. ${ }^{93}$ Whereas family law historically fixed family relationships and obligations in a sphere in which the scope for individual choice and personal proclivity were officially constrained - with parties born into gendered bodies with overdetermined scripts and then ushered into preconfigured institutions like marriage - the late $20^{\text {th }}$ century opened up to the prospect of greater individual tailoring of how marriage (and non-marital cohabitation) could meet the needs of its respective parties.

The centrality of status was eroded in the 1970s with the elimination of the concept of legitimacy for children of marriage, swiftly followed by a place for premarital legal agreements - "meretricious" agreements - in which parties to a

\footnotetext{
92 I will return to, and elaborate upon, this distinction between contractual and status-based understandings of the family.

${ }_{93}$ See, e.g., Janet Dolgin, Defining the Family: Law, Technology, and Reproduction in an Uneasy Age, (New York, NYU Press, 1997); and earlier, Mary Ann Glendon, The New Family and the New Property (Toronto: Butterworths, 1981)
} 
Fruitful Diversity: Revisiting the Enforceability of Gestational Carriage Contracts

Susan G. Drummond, Associate Professor, Osgoode Hall Law School

March, 3, 2013; Please do not cite without permission

marriage contemplated its dissolution and dealt prospectively with their assets. ${ }^{94}$ Judicial respect for domestic contracts - for the bargains of the parties themselves in derogation of state-generated default models - has only grown since their validity was recognized. ${ }^{95}$

The idea that contract was uniquely associated with commerce and therefore inappropriate to the protected domain of emotion and intimacy of the family has long given sway to the idea that contract law can be affiliated with, and tailored to, a range of different contexts that suggest particularized limitations. Juliet Guichon has recently promoted the idea that contract law has no place in family law, noting that "[c]ontract law is an essential tool of commerce and regards a deal as a deal. It assumes that people are autonomous, rational, self-interested and equal. However, family law accepts that people are interdependent, capable of irrationality, self-giving and vulnerable. ${ }^{96}$ In fact contract law is much broader than commercial contract law and has had a place in regulating the dissolution of adult interdependent relationships since a range of domestic contracts and their limitations were structured into family law legislation and case law in Canada over the last part of the $20^{\text {th }}$ century. If, as Guichon notes, family law "supervises the unraveling of solemnly

94 Child status legislation was modified in the 1970's province by province to eliminate the distinction between legitimate children (those issuing from a marriage) and illegitimate children (those born out of wedlock). For an early $20^{\text {th }}$ century decision that found domestic contracts unenforceable on the grounds that such agreements in anticipation of divorce were outside of the realm of contract altogether see Balfour v. Balfour [1919] 2 KB 571 (Eng. C.A.). Provincial family law reform following the 1968 Divorce Act provided for the the enforceability of domestic contracts; the role of contract expanded beyond that juncture to include non-married spouses, same-sex spouses, and the enforceability of contracts entered into postmarriage.

${ }^{95}$ See the leading cases of Miglin and Hartshorne referenced supra note 87

96 Juliet Guichon, "The body, emotions and intentions: challenges of preconception arrangements for health care providers" (2007) 176 Canadian Medical Association Journal 479 
Fruitful Diversity: Revisiting the Enforceability of Gestational Carriage Contracts

Susan G. Drummond, Associate Professor, Osgoode Hall Law School

March, 3, 2013; Please do not cite without permission

made marriage vows in divorce ${ }^{97}$ it does so very frequently by regulating the perfectly legal domestic contracts that the parties to the dissolution themselves create. The allure of the imagery of a stark divide between the private and public realms can generate a romantic fog about the family. The idea that "family law focuses on the body, emotions and changing intentions" is oblivious to the fact that a considerable bulk of family law is about property, custody and support at the dissolution of emotional entanglements. The narrow (and incorrect) view that contract law is the equivalent of the narrower field of commercial contract, when extrapolated into the reproductive domain, facilitates imagery associating reproductive arrangements with "products" and "widgets" and "commodification" and the assumption, as Francoise Baylis gratuitously puts it, that "the child is seen by the commissioning parents as a product". ${ }^{98}$

While family law establishes some context-specific limitations on domestic contracts through legislation and case law, taking into account the particular ways in which bargaining may not be equal between spouses, the practical reality is that courts largely and increasingly tend to honour such contracts. ${ }^{99}$ That many of these domestic contracts deal with both child custody and child support does not entail that family law has "commodified" children or failed to take account of their best interests or views them as a "product" or "property" of the parents.

\section{Contracts and Family Diversity}

\footnotetext{
97 Ibid

98 Both Guichon and Baylis construe reproductive arrangements as means of transforming children into "products", "widgets" and "commodities". See Tom Blackwell, "Couple urged surrogate mother to abort fetus because of defect" National Post, Oct 6, 2010

${ }^{99}$ Supra, note 87
} 
Fruitful Diversity: Revisiting the Enforceability of Gestational Carriage Contracts

Susan G. Drummond, Associate Professor, Osgoode Hall Law School

March, 3, 2013; Please do not cite without permission

Beyond the impact on children of the elimination of the importance of marriage for their status as legitimate or not, marriage itself has been stretched to incorporate a large range of diversity that bears tenuous relation to its previous patriarchal conception, the locus classicus of that transformation being same-sex marriage. The same movement that began to privilege individual choice and diversity over a prescripted status, as seen in these latter developments in family law, was manifest in the fading importance of the institution of marriage itself to socially-acceptable conceptions of the family. With the explosion in diverse socially and legally recognized ways of creating family came a commensurate loosening of the structures of family law, attended by struggles to find adequate alternative models to ground categories such as custody and spousal support. ${ }^{100}$ Overall, respect has been increasingly granted for the arrangements made between parties. Enlarging the scope for contracts within family law corresponded to increasing social recognition and respect for the diversity and flexibility of family possibilities outside of a narrowly construed use of status. Enlarging the place of contract in family law consolidated that individually-constructed diversity.

That family law has increasingly recognized the place of contract suggests not only that status-derogating bargains are tolerated in concert with the shifting substratum of social values over the last half century, but also that an increasing latitude is opening up for individuals to alter previously fundamental parts of the social structure. Gestational carriage contracts fit squarely into that social transformation as the status of parenthood - in particular motherhood - opens up to

100 See Beyond Conjugality, (2001), Law Commission of Canada; Brenda Cossman and Bruce Ryder, "What is 'Marriage-Like' Like? The Irrelevance of Conjugality" (2001) 18 Canadian Journal of Family Law, 269 
Fruitful Diversity: Revisiting the Enforceability of Gestational Carriage Contracts

Susan G. Drummond, Associate Professor, Osgoode Hall Law School

March, 3, 2013; Please do not cite without permission

alterations driven by individual tailoring. Just as regulation of domestic contracts, rather than their prohibition, is now readily used to overcome potential problems stemming from the familial context, it is worth asking whether the policy concerns the conceivable individual and social risks of gestational carriage contracts - can be modulated by context specific limitations on contract. ${ }^{101}$ Just as the substratum of values has shifted with the movement from status to contract in family law and the attendant diversity and flexibility of individual tailoring, the realities that subtend the practices surrounding assisted reproduction have provided a substratum of empirical evidence against which to measure policy concerns. If the evidence confirms that the risks, both social and individual, are considerable and unmitigable then the regulation proposed by the Uniform Act is well-advised. However if those risks have been greatly overplayed, then the structure of contract can be marshaled to create policy limitations in the sui generis area of gestational carriage contracts just as domestic contracts are shored up by sensitivities to the particularities of the family context.

\section{Empirical evidence}

An overall picture of the empirical realities of gestational carriage arrangements as they have developed in both regulated and unregulated settings suggests ways that contract law might be tailored to the specific context of reproductive technology. Limitations on freedom of contract can incorporate the vulnerabilities of women and children as demonstrated by observed, rather than anticipated, phenomena.

\footnotetext{
${ }^{101}$ As noted above, the California Surrogacy Law may be the beginning of how to imagine the requisite safeguards.
} 
Fruitful Diversity: Revisiting the Enforceability of Gestational Carriage Contracts

Susan G. Drummond, Associate Professor, Osgoode Hall Law School

March, 3, 2013; Please do not cite without permission

The evidence shows that the risk of intended parents failing to honour their part of the bargain and assume parental responsibility for the child carried by the surrogate is extremely minimal - to the point of being effectively non-existent in practice. ${ }^{102}$ The evidence also reveals that the incidence of carriers failing to honour the intentions entrenched in gestational contracts has been extremely low in Canada, UK and the USA since the Baby $M$ case in $1988 .{ }^{103}$ It might seem sensible, then, to keep the status quo unchanged instead of legislatively making gestational carriage contracts enforceable. Why tinker with something that is not broken and for which informal norms appear to govern effectively the needs and intentions of all contracting parties?

Further, there is evidence that those rare cases where the contract does not go well stem from a breakdown of the relationship between the carrier and the intended parents; ${ }^{104}$ and it seems that the current rule - that contracts cannot be enforced compels intended parents, through the risk of losing the child they have fostered in their hearts and imaginations, to "husband" the pregnancy in an honorable, caring, and respectful manner. Residual uncertainty in provinces that have not explicitly declared gestational contracts unenforceable seems to have the added and unstated bonus of policing disreputable conduct in intended parents.

The exceptional cases, however, underline the extreme conflict and emotional turmoil that can result when the intentions imbedded in the contract are not honoured. Further, the subjective measure of honorable treatment leaves a

102 Beyond reviewing the studies that researched the frequency of intended parents declining to pursue legal parentage - and finding the rate at the vanishing point Busby notes that "there is no evidence of commissioning parents rejecting children who do not meet their expectations." Revisiting Handmaid's tale at 78

103 Busby reviews the handful of cases where the intentions of the parties to a gestational carriage contract were not honoured at "Revisiting Handmaid's Tale", at 24 et seq

104 See review of empirical literature on this topic at 59 et seq of "Revisiting Handmaid's Tale" 
Fruitful Diversity: Revisiting the Enforceability of Gestational Carriage Contracts Susan G. Drummond, Associate Professor, Osgoode Hall Law School March, 3, 2013; Please do not cite without permission

considerable and weighty discretion in the private hands of the carrier that can depart radically from laudable social objectives, such as the minimization of discrimination on the grounds of marital status, sexual orientation, or disability. And dishonourable conduct might also include the exploitation by gestational carriers of the vulnerable and dependent position in which intended parents remain until they are declared legal parents - a vulnerability that lack of enforceability entrenches. The profile of carriers as an emerging professional class also suggests that an overemphasis on the governance of the relationship by analogy to respectful and supportive spouses may be inappropriate to the way that the carriers and commissioning parents have been constructing and construing the arrangement over the last 25 years.

These considerations aside, respecting the mater est rule in gestational carriage contracts may nevertheless be justified if there are more compelling social interests that override these problems. As noted above, the principle social interests cited to justify the non-enforceability of gestational carriage contracts are those of women and children. However, the empirical evidence suggests that those concerns, while once legitimate prospectively, are in fact overblown.

With respect to children, the anxiety underlying the unenforceability of gestational carriage contracts is that the individual child, born to a carrier and raised by intended parents, would feel abandoned by the woman who, it is assumed, would feel to them most like their mother. The concern with respect to children in general was that financial remuneration for gestational carriage services would tend to normalize the commodification of children. ${ }^{105}$ There is no empirical evidence that lends support to these worries. With children of gestational carriage contracts becoming a normal phenomenon over the last quarter-century, there is no evidence

105 See reference, note 8 
Fruitful Diversity: Revisiting the Enforceability of Gestational Carriage Contracts

Susan G. Drummond, Associate Professor, Osgoode Hall Law School

March, 3, 2013; Please do not cite without permission

that such children lament the loss of the woman who birthed them. Edelman summarizes the empirical literature by noting that there are

few, if any, psychological differences between children conceived by [assisted reproductive technologies] and those conceived naturally with regard to emotions, behaviour, the presence of psychological disorders or their perceptions of the quality of family relationships. ${ }^{106}$

Indeed, some studies suggest that there are higher levels of warmth and interaction within assisted reproduction families than in other families. One 2006 study concluded that "it appears that the absence of a genetic and/or gestational link between parents and their child does not have a negative impact on parent-child relationships or the psychological well-being of mother, father or children at age $3 " .{ }^{107}$

Adoption is a respected practice even though the biological and genetic mother yields parentage and custody to intended/social parents. As well, there is some evidence that some adopted children yearn for their biological and genetic progenitors. ${ }^{108}$ The practice of adoption has not been eliminated on this ground.

\footnotetext{
106 R. J. Edelmann, "Surrogacy: the psychological issues" (2004) 2212 Journal of Reproductive and Infant Psychology 123.

107 Sandra Golombok, Clare Murray, Vasanti Jadva, Emma Lycett, Fiona MacCallum, \& J. Rust., "Non-genetic and non-gestational parenthood: consequences for parentchild relationships and the psychological well-being of mothers, fathers and children at the age of 3"(2006) 21 Human Reproduction 1918.

108 The Pratten case in the Supreme Court of British Columbia recapitulates the legislative history that accompanied the understanding that closed adoption was not in the best interests of adopted children. See Pratten v. British Columbia (Attorney General), 2011 BCSC 656 (CanLII) (hereinafter Pratten) at para 178 et seq
} 
Fruitful Diversity: Revisiting the Enforceability of Gestational Carriage Contracts

Susan G. Drummond, Associate Professor, Osgoode Hall Law School

March, 3, 2013; Please do not cite without permission

There is also evidence that some children who have a genetic link through gamete donation can also yearn to connect with their genetic predecessors. ${ }^{109}$ However the evidence that the yearning to connect with a gestational carrier is present with children born of gestational carriage is highly limited - most particularly where the carrier is not genetically related to the child (which is the case in $95 \%$ of contemporary carriage arrangements). ${ }^{110}$

Cumulative research indicates that gestational carriage is regarded by the gestational carriers themselves as a compensable service contract rather than a contract for sale of goods. As noted above, the contractual relationship is falsely squared with commercial contract; domestic contracts, to provide a relevant example, are not commercial contracts. As with domestic contracts, the fact that the arrangement is consolidated via contractual instruments does not transform the children contemplated within them into commodities or property. ${ }^{111}$

Further, a woman who is both a genetic and biological parent can make the decision to terminate the pregnancy of a disabled foetus without their decision implying that they view children, including their current or future children, as "commodities". A critical disability analysis is available to assess parental choice to terminate the pregnancy in both gestational carriage and conception through coitus without either group of parents having more or less of a tendency to see a child "as a product, and a... substandard product because of a genetic condition," as Francoise Baylis puts it. ${ }^{112}$ The misconstrual of the place of contract in family law facilitates facile analogies that are not tethered to the empirical realities of how parents

\footnotetext{
109 These concerns are well represented in Pratten.

${ }^{110}$ Ragoné, cited in supra, note 91

${ }^{111}$ See the studies summarized in Revisiting Handmaid's Tale at 67 as well as the general empirical literature canvassed regarding the motivations and perspectives of gestational carriers (for citation see infra, note 114).

112 Supra, note 98
} 
Fruitful Diversity: Revisiting the Enforceability of Gestational Carriage Contracts Susan G. Drummond, Associate Professor, Osgoode Hall Law School March, 3, 2013; Please do not cite without permission

(intended, social, genetic or biological) conceive their offspring and make choices around them and with respect to the lives of each of them.

The fear that gestational carriage, even paid carriage, brings children closer to being conceived as commodities has not played out amongst the parties associated with the contracts. The case of the American surrogacy brokerage that impregnated carriers with embryos in the absence of intended parents and then sought to sell the children under the ruse that the intended parents were declining their part of the bargain has met with considerable opprobrium and Canada's first investigation under the $A H R A$. It stands out as a criminal anomaly against the backdrop of the paymentfor-service model of standard carriage contracts that creates children who go into homes as robustly loving as those who conceive through coitus.

The evidence around the vulnerabilities of carriers also calls into question the assumption that the non-enforceability of contracts protects those whose social and economic vulnerability would be compromised by such bargains. Two concerns have been associated with the presumed vulnerability of carriers: that they cannot give meaningful consent to relinquish a child without knowing how the experience of pregnancy might alter their feelings towards the child; and that the socio-economic asymmetries between intended parents and carriers makes them ripe for exploitation. ${ }^{113}$ Neither of these concerns have played out in the empirical evidence.

Busby's survey of the empirical literature on gestational carriage, to her own surprise, turns many of the feminist concerns that drove Canada's national policy on carriage on their head. ${ }^{114}$ While the feminist voices that predominantly shaped the Royal Commission on Reproductive Technology in the early 1990s construed

\footnotetext{
113 Supra, note 10

114 See "Karen Busby, "Revisiting the Handmaid's tale: Feminist Theory Meets Empirical Research on Surrogate mothers" 26 Can. J. Fam. L. 132010 (hereinafter "Revisiting Handmaid's Tale")
} 
Fruitful Diversity: Revisiting the Enforceability of Gestational Carriage Contracts Susan G. Drummond, Associate Professor, Osgoode Hall Law School March, 3, 2013; Please do not cite without permission

gestational carriage as a form of prostitution or slavery and regarded the carrier's undertaking not to bond with the child she carries as delusional and dehumanizing, the voices of the women who work as gestational carriers goes strongly against the grain of that analysis. The growing body of empirical research does not support concerns about pre-natal bonding or emotional instability during pregnancy. Gestational carriers consistently report the ability to detach early from connecting emotionally with the child and maintain that detachment throughout pregnancy and post-delivery. This detachment is facilitated by the overwhelming trend for gestational carriage arrangements to be gestational and not traditional - i.e., the carrier does not use her own ova. ${ }^{115}$ Gestational carriage has thus moved 180 degrees away from the practice at the time of the Baby $M$ case, when most surrogacies were traditional. Carriers consistently report thinking of the fetus as being for the commissioning parents (as their child), a position facilitated by their sense that the carriage is a job or a service with professional overtones and requirements. The emerging professional view of their work rejects the analogy to commercial contracts and the sale of goods; carriers overwhelmingly view their work as providing a meaningful and altruistic service, not different from services such as teaching, fire-fighting, or medicine. The construal of their undertaking as a service and the associated ability to detach emotionally from the foetus - is facilitated by the clear contractual (and enforceable) nature of the undertaking and by payment for the service.

The concerns about exploitation of carriers in light of socio-economic asymmetries between them and intended parents also appear to be largely attenuated by the evidence of practices that have emerged on the ground. Rather than the socio-economically fragile women contemplated in the prostitution/slavery

${ }^{115}$ Ragoné, cited in supra, note 91 
Fruitful Diversity: Revisiting the Enforceability of Gestational Carriage Contracts

Susan G. Drummond, Associate Professor, Osgoode Hall Law School

March, 3, 2013; Please do not cite without permission

analogies, carriers have been found to be more likely than the general population to be self-sufficient, independent thinkers. Karen Busby summarizes the research in the following way:

The profile of surrogate mothers emerging from the empirical research in the United States and Britain does not support the stereotype of poor, single, young, ethnic minority women whose family, financial difficulties, or other circumstances pressure her into a surrogacy arrangement. Nor does it support the view that surrogate mothers are naively taking on a task unaware of the emotional and physical risks it might entail. Rather, the empirical research establishes that surrogate mothers are mature, experienced, stable, self-aware, and extroverted non-conformists who make the initial decision that surrogacy is something that they want to do. ${ }^{116}$

Almost all carriers are familiar with the experience of family, having already had children and completed their own families; indeed, clinical practice reflects a trend to only work with women in these circumstances, ensuring that carriers have a sense of what it would be to surrender a child upon birth and a sense of the realities of pregnancy. ${ }^{117}$

The empirical research also reveals that the fears of a racialized underclass of carriers in North America has not panned out. Carriers tend to be Christian and Caucasian, but even where there are racialized differences between Carriers and intended parents, this has been interpreted by the carriers as something that facilitates their detachment from the foetus and their understanding that the child

\footnotetext{
${ }^{116}$ Revisiting Handmaid's Tale, at 51-52

117 See the studies summarized in Revisiting Handmaid's Tale at 41 et seq under sub-heading "Social, Racial, and Psychological Characteristics of Surrogate Mothers"
} 
Fruitful Diversity: Revisiting the Enforceability of Gestational Carriage Contracts

Susan G. Drummond, Associate Professor, Osgoode Hall Law School

March, 3, 2013; Please do not cite without permission

belongs to the commissioning parents. Carriers have varying degrees of education, but their incomes tend very infrequently to be in the range of financial distress. Their family incomes are most often modest (as opposed to low) and there is no convincing evidence that women on social assistance are significantly represented in the class of carriers. No empirical study in the materials reviewed by Busby indicates that carriers became involved with surrogacy because of financial distress. Rather than support the anxiety about vulnerable exploitable women, the research appears to consistently confirm that carriers feel empowered by their ability to use their bodies in a manner that generates a meaningful service through gestational carriage arrangements. ${ }^{118}$

\section{Conclusion}

All of this growing body of empirical research cited by Busby in her overview of the literature indicates that the overarching policy concerns that informed decisions to render gestational carriage contracts unenforceable - and, incidentally, to criminalize payment for service - are misplaced. The vulnerabilities of women and children are not non-existent; however, the empirical research indicates that those vulnerabilities may not be sufficiently acute, where they exist at all, to override the policy concerns (including the best interests of children) that might be furthered by enforcing regulated carriage contracts.

Further, the certainty created by treating gestational carriage contracts analogously to domestic contracts - i.e., that they will be enforced unless they fail to meet context specific limitations on the validity of contract, such as unconsionability,

118 Busby summarized a long list of empirical studies on these demographic characteristics of gestational carriers at pp $42-44$ (with references to the studies cited in footnotes 69 and following) 
Fruitful Diversity: Revisiting the Enforceability of Gestational Carriage Contracts

Susan G. Drummond, Associate Professor, Osgoode Hall Law School

March, 3, 2013; Please do not cite without permission

fraud, error, or duress, that take into account the unique settings of physical intimacy in which they are conceived - has the prospect of consolidating the emerging professional model of gestational carriage. Carriers are on notice from the outset of their undertaking that the children they give birth to will not be their legal children. As a professional community, this is the understanding of the service most carriers embrace. Potential emotional losses are easier to contemplate and prepare for psychologically under a certain rule that the contract will be enforced. Those women who are uncertain that they can manage the arrangement without ambivalence would be confronted with a clear rule that post-natal ambivalence will not be supported and a more certain outline of what the contract is asking of them. The current situation where it is uncertain whether or not a carriage contract would be enforced reinforces ambivalence throughout a pregnancy and up until the very moment that the child's legal parentage is lined up with intention. The certainty that gestational carriage contracts are null and void in jurisdictions like Quebec also prolongs ambivalence until the moment of adoption. The ambivalence persists even though, unlike adoption, the pregnancy in assisted reproduction is never entered into haphazardly or without awareness of the consequences of fertilizing ova and allowing the resulting embryo to develop in nurturing womb.

If the contracts were enforceable in law, a woman who enters a gestational carriage contract would be doing so knowing that the law speaks clearly on the implications of her decision - a result that would eliminate the harsh consequences for intended parents who are currently beholden to the carrier's potential ambivalence and exposed to considerable risks of emotional and financial loss and, in the current legal context, ongoing parental responsibilities if they are genetically related to the child (and quite possibly if they are not). The intended parents in gestational carriage contracts are after all not complete strangers to the child: they 
Fruitful Diversity: Revisiting the Enforceability of Gestational Carriage Contracts

Susan G. Drummond, Associate Professor, Osgoode Hall Law School

March, 3, 2013; Please do not cite without permission

are the parties but for whom the pregnancy would not have been initiated; ${ }^{119}$ and they intend from the outset to be actively involved in the child's care, whereas the gestational carrier does not.

All of these empirical and policy arguments comport with the emergence of a scholarly literature that favours intention over gestation in carriage contracts. ${ }^{120}$ Emerging in tandem with increasing use and normalization of gestational carriage is an awareness that the practice generates little tangible harm, and that those residual harms would best be addressed by explicit regulation. The general hiatus in modifying child status legislation to deal explicitly with gestational carriage (with the exceptions of Quebec, Alberta and British Columbia) has afforded a pause to more thoughtfully balance the risks to all parties without the alarm and hostility that followed on the Baby $M$ case. It would be regrettable at this juncture and given what we now know about gestational carriage to follow a model, such as the one proposed in the Uniform Child Status Act, that is hinged to an outdated understanding of the realities on the ground.

${ }^{119}$ As per Johnson v. Calvert and Buzzanca cited above

120 See, e.g., Kirsty Horsey, "Challenging Presumptions: Legal Parenthood and Surrogacy Arrangements", Child and Family Law Quarterly, vol 22, No 4, 2010; See also Elizabeth S. Scott, "Surrogacy and the politics of commodification", Law and Contemporary Problems 72.3 (Summer 2009); and for earlier articles, Marjorie Maguire Shultz, "Reproductive Technology and Intent-based Parenthood: An Opportunity for Gender Neutrality", 1990 Wis L. Rev. 297; John Lawrence Hill, "What Does It Mean To Be a "Parent"? The Claims of Biology as the Basis for Parental Rights" ,66 N.Y.U. L. Rev. 353 (1991); Richard Storrow, "Parenthood By Pure Intention: Assisted Reproduction and the Functional Approach to Parentage" 53 Hastings L.J. 597 2001-2002 
Fruitful Diversity: Revisiting the Enforceability of Gestational Carriage Contracts Susan G. Drummond, Associate Professor, Osgoode Hall Law School March, 3, 2013; Please do not cite without permission 